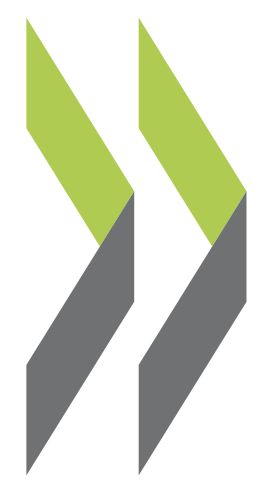

OECD Science, Technology and Industry Working Papers $2002 / 03$

The Importance of Entry to Canadian Manufacuring, with an Appendix on Measurement Issues

\section{John R. Baldwin,}

Desmond Beckstead, Andrée Girard 
Organisation de Coopération et de Développement Economiques

DIRECTORATE FOR SCIENCE, TECHNOLOGY AND INDUSTRY

STI WORKING PAPERS 2002/3

THE IMPORTANCE OF ENTRY TO CANADIAN MANUFACTURING

John R. Baldwin, Desmond Beckstead and Andrée Girard 


\section{STI Working Paper Series}

The Working Paper series of the OECD Directorate for Science, Technology and Industry is designed to make available to a wider readership selected studies prepared by staff in the Directorate or by outside consultants working on OECD projects. The papers included in the series cover a broad range of issues, of both a technical and policy-analytical nature, in the areas of work of the DSTI. The Working Papers are generally available only in their original language - English or French - with a summary in the other.

Comment on the papers is invited, and should be sent to the Directorate for Science, Technology and Industry, OECD, 2 rue André Pascal, 75775 Paris Cedex 16, France.

The opinions expressed in these papers are the sole responsibility of the author(s) and do not necessarily reflect those of the OECD or of the governments of its Member countries.

http://www.oecd.org/sti/working-papers 
DSTI/DOC(2002)3

\title{
THE IMPORTANCE OF ENTRY TO CANADIAN MANUFACURING, WITH AN APPENDIX ON MEASUREMENT ISSUES
}

\author{
John R. Baldwin", Desmond Beckstead ${ }^{* *}$ and Andrée Girard** \\ Microeconomics Analysis Division \\ Statistics Canada
}

\begin{abstract}
Understanding the importance of the dynamic entry process in the Canadian economy involves measuring size of entry. The main purpose of this paper is to summarise the information that we have on the amount of entry in Canada.

The paper also fulfils another purpose. Some studies have focused on cross-country comparisons (Geroski and Schwalbach, 1991: OECD, 2001). Interpretation of the results of these studies is difficult unless methodological issues regarding how entry is measured are addressed. Without an understanding of the extent to which different databases produce different results, international comparisons are difficult to evaluate. Cross-country comparisons that are derived from extremely different data sources may be misleading because of the lack of comparability.

Since there is more than one reliable database that can be used to estimate entry in Canada, this paper asks how measured entry rates vary across different Canadian databases. By examining the difference in entry rates produced by these databases, we provide an estimate of the range or confidence interval that should be used in evaluating whether there are real differences in measured entry rates across countries. We also offer guidance as to the questions that should be asked about the databases used by researchers who conduct international studies. Finally, we make suggestions as to areas of comparison on which international studies should focus.
\end{abstract}

\footnotetext{
* Director, Microeconomics Analysis Division; Tel: +1 613-951-8588; E-mail: john.baldwin@statcan.ca. Corresponding author.

** Researcher, Microeconomics Analysis Division; Tel: +1 613-951-6199; E-mail: beckste@statcan.ca

*** Researcher, Microeconomics Analysis Division; Tel: +1 613-951-8581; E-mail: andree.girard@statcan.ca
} 


\title{
L'IMPORTANCE DE L'ENTRÉE DANS LE SECTEUR CANADIEN DE LA FABRICATION, DOCUMENT ACCOMPAGNÉ D'UNE ANNEXE SUR LES QUESTIONS DE MESURE
}

\author{
John R. Baldwin*, Desmond Beckstead** et Andrée Girard*** \\ Division de l'analyse microéconomique \\ Statistique Canada
}

\section{Résumé}

Il faut mesurer l'étendue de l'entrée dans l'économie canadienne pour comprendre l'importance du processus dynamique d'entrée à l'intérieur de cette économie. Le présent document a principalement pour objectif de résumer l'information dont nous disposons sur l'envergure de l'entrée dans l'économie au Canada.

Il réalise également un autre objectif. Certaines études sont axées sur des comparaisons entre pays (Geroski et Schwalbach, 1991; OCDE, 2001). Il est difficile d'interpréter les résultats de ces études à moins d'aborder des questions méthodologiques qui se rattachent à la façon de mesurer l'entrée dans l'économie. Il est également difficile d'évaluer des comparaisons au niveau international si l'on ne comprend pas à quel point des bases de données différentes produisent des résultats différents. Les comparaisons entre pays établies à partir de sources de données extrêmement différentes peuvent être trompeuses en raison de leur manque de comparabilité.

Parce qu'il existe plus d'une base de données fiable pouvant servir à estimer l'entrée dans l'économie au Canada, nous nous demandons à l'intérieur du présent document à quel degré les taux mesurés d'entrée varient d'une base de données canadienne à une autre. En examinant l'écart entre les taux d'entrée produits par ces bases de données, nous y fournissons une estimation de la plage ou de l'intervalle de confiance qu'il faudrait utiliser pour évaluer s'il existe d'un pays à un autre des différences réelles sur le plan des taux mesurés d'entrée. Nous offrons aussi aux présentes des orientations relativement aux questions que devraient poser à propos des bases de données les chercheurs effectuant des études internationales. Nous y formulons finalement des suggestions au sujet des domaines de comparaison sur lesquels les études internationales devraient être axées.

\footnotetext{
* Directeur, Division de l'analyse microeconomique; Tel: +1 613-951-8588;

E-mail: john.baldwin@statcan.ca

** Chercheur, Division de l'analyse microeconomique; Tel: +1 613-951-6199;

E-mail: beckste@statcan.ca

*** Chercheur, Division de l'analyse microeconomique; Tel: +1 613-951-8581;

E-mail: andree.girard@statcan.ca
} 
TABLE OF CONTENTS

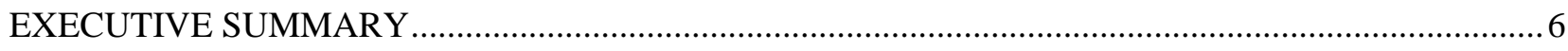

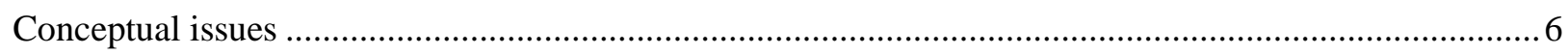

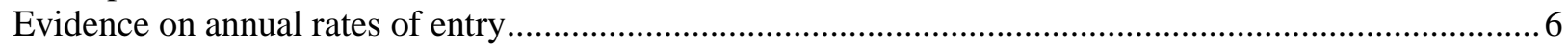

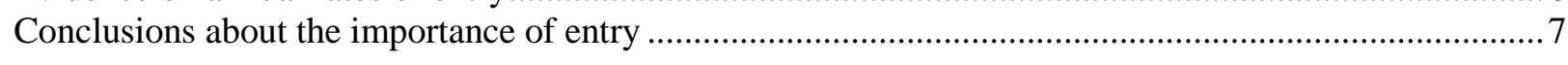

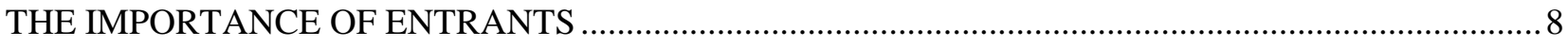

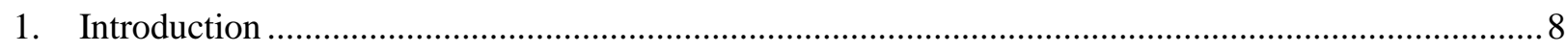

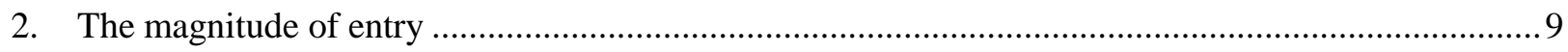

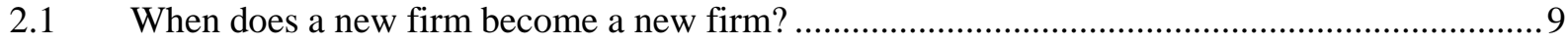

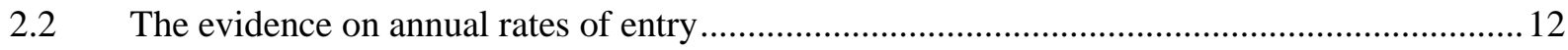

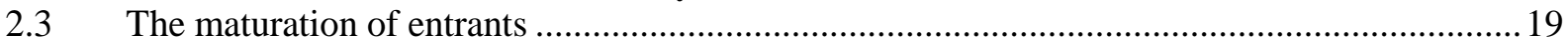

2.4 The evidence on the effect of long-run entry on employment ...............................................21

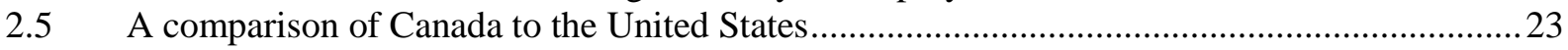

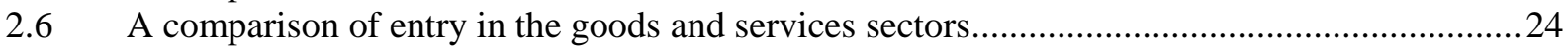

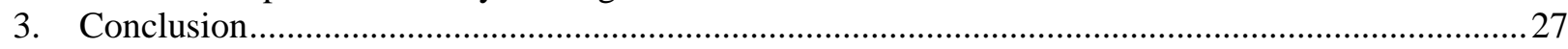

APPENDIX A CHOICE OF DATABASE FOR RESEARCH PURPOSES ............................................29

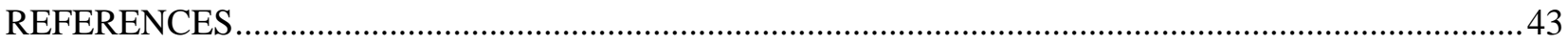




\section{EXECUTIVE SUMMARY}

The paper presents estimates of the importance of entry in Canada using three different databases. It is meant to provide not only estimates of the importance of entry but also approximations to the nature of the size of the confidence intervals that should be placed around these estimates for the purposes of crosscountry comparisons. Since there is more than one reliable database that can be used to estimate entry in Canada, this paper asks how measured entry rates vary across different Canadian databases. In doing so, the paper provides estimates of the range that should be used in evaluating whether there are real differences in measured entry rates when conducting studies of the differences in entry rates across countries.

\section{Conceptual issues}

The first section of the paper deals with important conceptual issues that need to be resolved before settling on specific measures of entry that will be used for cross-country comparisons of entry rates.

First, it is noted that entry measures will tend to differ across databases, because the point at which a new business entity is captured in different databases differs for administrative reasons. The earlier in the process, the larger are the calculated entry rates.

The section also notes that databases can differ substantially in terms of the accuracy with which they measure producers that are "truly" new. However, it also notes that there is no definition of "truly" new that will satisfy all research purposes.

The third section of the methodology section deals with areas where decisions on the way in which entry is to be measured once again rest on the purpose of the study - whether entry should be measured as the number of new enterprises, or some measure of size (sales, employment); whether it should be measured in the short or long run (over periods of one year, five years, or even longer periods); whether economy-wide estimates should be measured as an unweighted or weighted average across industries. Different choices in each of these areas will give quite different pictures of the importance of the entry phenomenon. In the paper, the entry rates are calculated both using numbers of firms and size of employment to show the differences between the two. Both short and longer-run results are shown to give the reader an understanding of these differences. Finally, where it is feasible, the effect of including mergers on measured entry rates is examined.

\section{Evidence on annual rates of entry}

The second section of the paper examines the size of entry rates derived from two Canadian administrative files and one survey file. The study examines differences for annual and five-year entry rates, calculated first as the percentage of firms that have just been born and the percentage of employment in new firms. 
This study shows that short-run entry rates calculated using number of firms are highly sensitive to the comprehensiveness of the database, but less sensitive to this factor when employment-weighted estimates are used. Differences in the results when different databases are used are less than when long-run rates are used or when annual rates are averaged over several years to smooth out the idiosyncrasies that exist in the microeconomic databases that are used to measure entry. The percentage of firms entering and surviving to a point in the future is quite similar across the databases used here.

The paper also argues that entry statistics that measure importance using employment are less susceptible to idiosyncratic cut-offs associated with different databases, but are more sensitive to the definition of entry - in particular whether mergers are included in the definition of entry. In Canada, there is a substantial amount of annual turnover due to control changes. Entry rates that include most mergers will be much higher than those that are purged of this form of turnover.

\section{Conclusions about the importance of entry}

The entry measures presented herein show that the dynamic process that brings new firms into an industry and forces old firms out of industries dramatically reshapes the Canadian industrial landscape. On an annual basis, a large number of firms attempt to break into markets each year. In Canada, somewhere between $15 \%$ and $20 \%$ of all firms are new each year - with a slightly higher percentage in services than in manufacturing. The impact on employment of a single year's entry cohort is less, since entrants are on average smaller than the average firm in an industry. Depending on how the size of new firms is measured, firms that have entered in the preceding year account for between $2 \%$ and $4 \%$ of employment on average.

On the other hand, if we examine entrants who survive for five years, firm entry rates are lower than if we measure entry on a year-to-year basis. Using number of firms, the five-year surviving entry rate ranges from $5 \%$ to $6 \%$ (compared to the $15-20 \%$ one-year rates); on the other hand, five-year employment entry rates are not much lower than one-year rates; the five-year surviving entry rate using employment as a metric is about $2.5 \%$ for the economy as a whole (much the same as the one-year rate). Despite the fact that a large number of firms die by their fifth birthday, the survivors grow so much that the importance of the entry cohort is more or less maintained over the first five years of existence.

The impact of entrants can be measured not just in terms of firms that had entered in the previous year, but in terms of the cumulative effect of five or ten years of new firms. Not all entrants will survive to be counted in such an estimate - but a large enough group will do so to ensure that the cumulative effect of entry mounts up as the time period used to measure the phenomena increases. In the manufacturing sector, ten years of entrants account for some $16 \%$ of shipments; 20 years of entrants account for about $34 \%$ of shipments. These long-run estimates are equally high in the services sector.

In conclusion, entry in Canada is important for two reasons. First, a large percentage of firms in any period are recent entrants. And while many new firms do not survive, some do and they grow. Taken together, successive cohorts of recent entrants, both the more and the less mature, account for a significant proportion of output at any point in time. 


\section{THE IMPORTANCE OF ENTRANTS}

\section{Introduction}

Markets are in a constant state of flux (Agarwal and Gort, 1996). Continuous competition leads some firms to grow and others to decline. The amount of market share transferred in a typical Canadian manufacturing industry in the 1970s ranged between $30 \%$ and $40 \%$ (Baldwin, 1995). It is this change that causes continuous renewal in industry. An important part of this turnover comes from the entry and exit of firms.

Entry is of interest for several reasons. It is a barometer of the state of the economy. The driving force behind a new firm is an entrepreneur, and an entrepreneurial economy is one that is dynamic and innovative. An entrepreneurial economy takes risks to produce new products and to create new forms of wealth. It is an economy that experiments with new ideas and new processes. It is an economy that renews itself, and an important source of renewal comes from entry.

Each year large numbers of entrepreneurs start new firms. For the majority of these firms, life is short. Most new entrants exit shortly after birth (Baldwin et al., 2000). This process provides the stimulus for entrepreneurial learning. Experimentation associated with entry is the key to a dynamic market-based economy.

New small firms provide an important stimulus to the industrial population (Rothwell and Zegveld, 1982; Rothwell, 1989). Most entrants are small relative to the existing firm population (Baldwin 1995; Audretsch, 1995). A few small entrants grow to become the new dynamos of the industrial system. Others remain relatively small but provide an important source of innovation in the small-firm sector - especially when it comes to quality differentiation.

Smaller firms excel in their ability to provide quality products and flexibility of service (Baldwin et al., 1994; Baldwin et al., 1998). Small firms are adept at ascertaining changing consumer tastes with regards to the amount of services that are bundled with a product, or being flexible with regards to other aspects of the product offering. New small firms that are better able to sense consumer requirements are constantly replacing other small firms that are less able to do so.

One manifestation of the success of small entrants is their tendency to pay higher wages and to be more productive than those firms that they force out of the market (Baldwin, 1995; 1996). In this respect, they force a discipline on incumbent firms. It is the process of entry that helps to generate information on which combinations of products and services best satisfy consumer tastes.

A first step in understanding the importance of this dynamic entry process in the Canadian economy involves measuring the size of entry. The main purpose of this paper is to summarise the information that we have on the amount of entry in Canada.

The paper also fulfils a second purpose. Some studies have focused on cross-country comparisons of the intensity of entry (Geroski and Schwalbach, 1991; OECD, 2001). Interpretation of the results of these studies is difficult unless methodological issues regarding how entry is measured are addressed. Without an understanding of the extent to which different databases produce different results, international comparisons are difficult to evaluate. Cross-country comparisons that are derived from extremely different data sources may be misleading because of the lack of comparability. 
Since there is more than one database that can be used to estimate entry in Canada, this paper attempts to provide some guidance to international studies that compare entry. In this paper, we ask how measured entry rates vary when different Canadian databases are used for measurement purposes. In doing so, we provide an estimate of the range or confidence interval that should be used in evaluating whether there are real differences in measured entry rates across countries. We also offer guidance as to the questions that should be asked about databases by researchers who conduct international studies. Finally, we make suggestions as to areas of comparison on which international studies should focus.

\section{The magnitude of entry}

Entry is at the heart of two quite disparate economic paradigms. On the one hand, new entrepreneurs are seen to be the key building block in the economic system (Knight, 1921; Kirzner, 1972). On the other hand, the traditional neo-classical approach portrays entry and exit as one of the equilibrating forces that drive down above-normal profits in an industry and equate price and average cost in an industry. ${ }^{1}$ Since entry plays a prominent role in both models, we will examine the quantitative evidence to see if it supports the notion that entry is important. We proceed to answer four questions. First, what is the annual or instantaneous rate of entry? Second, what is the survival rate of entry - the rate of entry when we consider only those firms who survive to early infancy? Third, we ask what the relative importance of entry is when measured using number of firms as opposed to employment. Fourth, we illustrate the first three issues with concrete examples from the goods-producing and the services-producing sectors.

\subsection{When does a new firm become a new firm?}

If the significance of entry is to be appreciated, then quantitative measures of the importance of new firms are required. We need estimates of the significance of the effect of entry on existing markets. These measures can be aimed at telling us what percentage of the market has just been renewed (for example, over the last year) or what percentage has been renewed over a longer period (for example, over the last five or ten years).

Initially, empirical studies of the entry process were restricted primarily to case studies (i.e. Mansfield, 1962). With the advent of large micro-databases, this has changed. Many studies have emanated from statistical agencies that computerised their files on firm populations during the 1970s and 1980s. These databases originate from official statistical agency files that most frequently cover the manufacturing population (e.g. the LRD at the US Bureau of the Census), or from private sector sources such as the longitudinal file that was developed at the Small Business Administration from Dun and Bradstreet records. Similar files exist in other countries. For example, Canadian files have been derived from data on manufacturing firms that were collected by the Census of Manufactures (see Baldwin, 1995) and a more extensive file on the population of all employer firms derived from tax records (see Baldwin, Dupuy and Penner, 1992). Other countries have developed files - often from administrative sources such as social security records (OECD, 1996).

There are several important questions that need to be answered before we derive measures of entry.

First, what is the correct conceptual measure of entry? Ascertaining what the correct conceptual rate of entry is requires that we specify what an entrant is, or more precisely: when does a new firm become a new firm? New firms go through several stages. They may just be an idea in an entrepreneur's mind, or a tentative experiment that may consist only of the founder working in a garage or home office. Usually at a

1. For a number of empirical studies that adopt this approach, see Geroski and Schwalbach (1991). 
later stage, these new entrepreneurs begin to hire employees. At a still later stage, they are incorporated into official business registers and surveyed either by a statistical agency or by a credit-rating agency.

It is clear that there is no "correct" time at which entry should be measured. Even if it were defined as the first economic transaction, a decision would have to be made on the type of transaction that would trigger a birth. Most databases capture firms at an arbitrary point in their birthing experience - when they hire their first worker, or make their first sale, or pay taxes for the first time.

If the population of entrants being measured consists of all individuals who are just beginning to formulate ideas for the establishment of a new business, the entry rate will be different than if it covers new firms that have taken a commitment to create the infrastructure required to start operations. The earlier in the entry process, the higher are the entry rates, because there are far more people who conceive of ideas for a new business than ever get to the stage where they hire workers and begin production.

The various databases that measure entry capture a new firm at an arbitrary and potentially different point in its initial development. Rather than argue that one point in time is preferable to another, it is better to clearly define what that point is so that differences in levels of entry rates can be related to differences in the point at which a new firm is first captured.

It is also important to understand the factors that cause a new entity to appear in the databases that are used to measure entry. The creation of a new firm may correspond to the receipt of a business registration number, or to the hiring of employees, or to the first tax filing. However, the issuance of these business numbers may differ substantially across countries. In some cases, entry is triggered in these databases by the appearance of a brand new firm that arrives in an industry by building new plants - what we call "greenfield entry". In other cases, it is brought about by organisational changes, such as mergers - what we can call "entry by merger".

\subsubsection{Accuracy of estimates}

Even after these conceptual issues are resolved, there are important practical data considerations that need to be considered if the meaning of entry rates derived from a particular database is to be fully understood. Entry is measured as the appearance in administrative files of a new firm. Entry is whatever event causes the administrators of these files to decide that a firm submitting data deserves a new record number; otherwise the data for the entity would be assigned to a firm that in some previous period already existed.

Unfortunately, many files were not originally established with clear rules as to when old recordidentifiers would be terminated and new record-identifiers birthed. In some files, ongoing firms are arbitrarily assigned new record numbers from time to time. When this is done, an ongoing entity falsely appears to die and then be born. This often arises when a merger, amalgamation, or a change in ownership or control takes place. If this occurs, the number of measured births produced by these files includes mergers. If the researcher wants to focus on new firms that are associated with the creation of new jobs in new plants, then entry rates that contain mergers and other forms of organisational change are too large. However, they are appropriate if the purpose of an entry study is to measure the emergence of new entities - both those that are greenfield and those who have gone through a major form of reorganisation.

Two approaches can be taken to shed light on how serious a problem this is and then to correct the problem. First, detailed estimates of the error rates can be derived by sampling the database and investigating the error rate. ${ }^{2}$ Second, outside information can be used to correct the database. For example,

2. See Baldwin (1995) for the work done on the Canadian manufacturing database to estimate the error rate. 
the Canadian longitudinal file derived from tax records tracked workers over time to correct for births and deaths that arise from some type of organisational change (Baldwin, Dupuy and Penner, 1992).

All of this is to say that annual entry rates for the same country can differ when they are calculated from databases that differ in terms of coverage and the type of event that triggers the emergence of a new firm on these databases. This means that different databases generate different impressions about the extent of dynamic change within the industrial landscape. In this paper, we delineate the size of these differences.

\subsubsection{Definitional issues}

There are a number of other issues where decisions need to be taken before entry rates are calculated. These are: whether the rates are calculated using number of new plants or new firms; whether we use the percentage of entities (establishments or enterprises) that are entrants or the percentage of employment that is accounted for by entrants; whether we look at the short run or the long run; and which sector is chosen to calculate entry rates.

First, we can focus on either establishments (plants) or enterprises (firms). Plants are the lowest levels of operating entity on which statistical agencies focus. A plant may or may not correspond to a single physical location. In some instances, multiple physical locations are grouped together. Enterprises are groups of establishments. These groupings may correspond to legal entities, or they may be the lowest level at which certain data (i.e. financial data) can be collected. The limiting case is the firm that consists of all establishments under common control. International studies must recognise that the level at which a "firm" is defined varies across countries.

Generally, the higher the level of aggregation used, the lower the rate of entry that is calculated. When calculated at the plant level, new plants created by existing firms will be classified as entry, whereas this event would not be counted as entry at the firm level.

Second, entry rates calculated using the number of new firms that enter an industry will differ from those calculated using a measure of size (such as the employment in entrants calculated as a percentage of total employment). This occurs because entrants are smaller than the average continuing firm.

Databases will also differ in terms of their comprehensiveness when different rules are used to define a new firm. Some rules catch the arrival of new firms earlier than others. The ones that capture new firms earliest report the highest entry rates when entry rates are defined as the percentage of firms in a given period that are new. This is because the very earliest firms to enter an industry have a much higher exit rate. Nevertheless, these firms are also very small and their omission from a database will have very little impact upon entry rates calculated using employment or shipments. ${ }^{3}$

Third, entry rates will differ depending on which industries are examined and whether entry rates are calculated as weighted or unweighted averages. The intensity of entry varies across sectors. Because of this, the rate of entry will differ depending whether the rates are calculated using a weighted or unweighted average - that is, if all industries are taken together (the sum of all entrants over the sum of all firms) or if the entry rate is calculated for each industry individually and then averaged. Weighted entry rates will be lower than unweighted averages when the largest sectors tend to have the lowest entry rates.

Fourth, entry rates will vary depending on whether they are calculated over short periods (i.e. one year) or over longer periods of time (i.e. five or more years). The latter, when annualised, will generally be

3. See Baldwin and Gorecki (1990) for a discussion of this point. 
lower than the former because those entrants who fail sometime during the first four years are removed from the measure. Rates calculated over a longer period give a better picture of the importance of entrants who are more permanent, although both entry rates are useful for analysis. High short-run or annual entry rates accompanied by low long-run entry rates indicate that the experimentation process is high relative to its long-run impact.

In the following sections, we illustrate the sensitivity of calculated entry rates to the choice of a database. To do so, we examine the differences generated by the use of several alternatives: calculating entry rates as the percentage of new firms or as the percentage of employment in new firms; calculating entry rates over the short as opposed to the long run; and calculating them in the goods as opposed to services sectors. We show that differences are large in some dimensions, but not in others.

\subsection{The evidence on annual rates of entry}

A new firm goes through several initial stages. An idea for a new entity is conceived; an individual begins to devote time and effort to bringing that idea to fruition, sometimes by devoting less time to paid employment activity; space may be hired and assets purchased to prepare for the launching of the new firm; and then employees may be hired to begin or assist in the production process.

In what follows, we use several different databases to measure the rate of entry to Canadian industry to show the type of differences that emerge from the use of three different databases that capture entry at different points in the new firm's lifecycle. The first uses data on early stages of firm formation. The second captures the stage where employees are first hired. The third captures new firms when they show up in a production survey for the manufacturing sector.

\subsubsection{Entry to self-employment}

The very earliest stages of the firm are difficult to capture - although data on self-employment are sometimes used for this purpose. ${ }^{4}$ When individuals begin to develop new ideas outside of their main paid job, they will eventually begin to receive self-employment income in response to their efforts. Some of the newly self-employed are starting successful businesses that will go on to grow and to create large-scale businesses in the future. As such, this group is sometimes defined as being equivalent to the entrepreneurial class.

While this group, no doubt, includes entrepreneurs who are in the process of trying to create firms that will eventually grow to provide jobs for others, it also includes many who are simply employees being paid under contract rather than on an hourly basis or who are satisfied with a small operation without employees and the limited income derived therefrom.

The self-employed have become relatively more important in Canada over the last two decades, increasing from around 12\% of total employment in 1976 to some 17\% in 1997 (Statistics Canada, 1997a).

4. A profile of the self-employed is available from two sources. The first is a household survey (the Labour Force Survey) that defines the self-employed to include working owners of incorporated businesses, working owners of unincorporated businesses and self-employed who do not run a business such as newspaper carriers, and unpaid family workers (see Statistics Canada, 1997a). The second is derived from tax records and defines the self-employed on the basis of whether any professional, business, commission, farming, fishing or other non-employment income is reported (see Statistics Canada, 1997b). 
Men are more likely to be self-employed, but the self-employment rate has been increasing for both men and women. ${ }^{5}$

We can measure entry to the self-employed group by calculating the percentage of total self-employed in any year that have just become self-employed. When the tax files are used and self-employment is defined as those whose dominant form of income is derived from self-employment, entry rates to selfemployment in Canada are high. On average, some $22.4 \%$ of the self-employed in any year are new entrants to the self-employed group (Lin, Picot and Yates, 1999). Defining self-employment as the reporting of any income from self-employment yields an average entry rate of $15 \%$ for men and $24 \%$ for women (Statistics Canada, 1999).

It should, however, be recognised that a substantial proportion of the self-employed are not there to create production entities of any substance - either in terms of sales, employment or capital formation. Nor do they fall into the category of dynamic entrepreneurs in the usual sense of the word. In some occupations, employees are more likely to be self-employed-farmers, artists, construction workers or sales agents (Statistics Canada, 1997a). This is sometimes done to create a remuneration package that is better geared to providing incentives in situations where monitoring of worker performance is difficult. In this case, it is difficult to equate the self-employed in this category with emerging industrialists; although, if this reason for the emergence of the self-employed is correct, the increase in their number may still indicate that a different skill set is now required of the workforce - skills like self-reliance and independence that are required in situations where monitoring and supervision are utilised less.

Other studies have suggested that taxation partially accounts for the existence of the self-employed and the recent change in the self-employment rate. By switching workers from an employee to a selfemployment status, firms may decrease their employment costs if they can avoid paying certain fringe benefits or if this allows workers to take larger tax deductions from earnings, and businesses can capture part of the resulting gain in net income. In this case, the self-employed do not so much represent a pool from which the new business owners of tomorrow are likely to emerge as a group of workers who receive a different remuneration package than others, since they include contract workers, both post-retirement and otherwise.

Finally, self-employment may result when a paid employee is pushed from employment to selfemployment by poor economic circumstances. The transition from full-time employment status to a combination of part-time employment and part-time self-employment is more likely if a worker is receiving lower wages from employment (Tompa et al., 2000). In the same way, a worker is more likely to make a transition back from self-employment to full employment status, the higher the wage earned in employment while the individual continues to earn some self-employment income (Statistics Canada, 2000). At least for women, the probability of moving out of self-employment is higher where her spouse is doing relatively better. In an economy where employment income is lagging, we would therefore expect to find higher rates of self-employment although this type of self-employment may not engender the type of new firm that is likely to grow and contribute to overall employment or productivity growth.

These various arguments suggest that it is difficult to sort the self-employed into those who will become the heads of growing enterprises of the future and those who have been forced into this situation by their type of occupation or a poor economy and would prefer other forms of employment. Evidence indicates that fewer and fewer self-employed in the 1990s are hiring others to work for them. The percentage of incorporated and unincorporated self-employed who have employees has fallen steadily in

5. Tax data show a difference with the LFS data. The former show the rate of self-employment increasing more rapidly for women, especially young women, than men, who have had relatively constant selfemployment rates in the 1990 s. 
recent years from a high of over 46\% in 1988 to less than 34\% in 1997 (Statistics Canada, 1997a). Rapid employment growth at the end of the 1990s has been accompanied by a slowdown in self-employment growth in Canada.

\subsubsection{Entry as measured from administrative files}

Because of the difficulties in measuring self-employment and the conceptual problems in equating it to the creation of new firms, most entry studies rely on a different point in a firm's life cycle to define the birth of a new firm. Most measures of entry capture a new firm when it shows up on an administrative file, which may correspond to the hiring of the first employee. It is this particular transition in the life of a new entity when a major step is taken to assemble resources to create a sizeable firm. It is not the first step in the creation of an entity; that has been taken before workers are hired. It is not even the first step taken in assembling resources: a sizeable proportion of firms that hire employees have already acquired other assets - in the form of plant and equipment. Nevertheless, the hiring of workers is a clearly delineated step in the growth of the firm that is seen to provide the benefits of jobs to the labour force.

Therefore, for this study, we calculate the rate of entry to the population of firms who are employers by examining the rate at which new employers are created. We use two different but related administrative databases that allow us to gauge the effect of the use of different concepts to define the "entry of a new firm". Entry rates are defined as the number of entrants (those firms that existed in period $t$ but not in period $t-1)$ divided by the population of firms in period $t$. Both databases allow us to calculate the proportion of the total number of firms with employment that were "new" at a point in time. However, the definition of "new" varies, as it does across almost all databases that are used to calculate entry rates.

A new firm may be defined as a firm that consists of a new legal entity; that possesses a new owner or a new manager; that shifts from one line of business to a new line of business; that shifts location, or that has been involved in a major reorganisation - such as a merger or some other change in the way that a firm structures its business operations. Or a new firm could be defined as involving various combinations of each of the above. The rate of entry calculated from any database will be a function of how many of these types of events trigger the signal that is used to measure the existence of a new firm.

The first entry rate is calculated from a file that keeps track of all commercial ${ }^{6}$ firms in Statistics Canada's Business Register - the file that is used to track the universe of firms that are used for Statistic Canada's production surveys. In this section, we use the universe of employers in the Business Register over the period 1989 to 1997 to examine the number of firm births in each year that have employees. The files from the Business Register are generally comprehensive. The accuracy of Statistics Canada's collection programmes depends on the maintenance of an accurate picture of the universe from which the agency chooses samples for its business surveys.

The creation of a new entity in these files can arise from a number of events. Researchers may not want to include some of these in a definition of a "new" firm. There are both conceptual and operational issues associated with any decision as to which events should be used to define a new firm. Conceptual issues relate to the concept of a new firm that is desired for a particular piece of research. Operational issues involve the ability of a particular file to measure the desired concept of entry.

The Business Register is built from files that keep track of the remittances that firms must make when wages are paid - remittances for pensions, unemployment insurance and withholding taxes. When a new

6. Firms in the non-commercial sectors of health, education and government are included in the Business Register list at Statistics Canada but are excluded from this study. 
entity registers with the taxation system (when a firm chooses to apply for a new business number), a new firm is logged onto the Business Register. Some of these new registrants are new businesses in the sense that they are unrelated to any previous business; some new registrants are existing businesses that have only just hired employees. Some new registrants are existing businesses that have changed location, that have changed ownership, or that have simply restructured their payroll accounts (see Baldwin et al., 2000, Appendix).

A conceptual problem occurs when there is disagreement about how to specify what a new business should cover for entry measures. Some researchers may wish to define births in a narrower sense than occurs from the operation of the registration system - for example, as not involving changes in location or reorganisation. ${ }^{7}$ If so, the entry rates generated from the Canadian Business Register (and many other files) will overestimate the rate of renewal of entirely new firms. The degree of overestimation will depend on the rigidity of the rules and the diligence with which they are applied by the database administrator in removing these forms of reorganisation from the register. However, caution should be exercised before researchers adopt too stringent a position on what should be defined as new. For example, a reorganisation of a firm that is associated with its choosing to take out a new business number can involve a significant form of renewal. In surveys, we have found that many of the reorganisations captured on the Business Register were dramatic - for example, involving a son or daughter taking over the family business and completely changing the nature of the business.

The Business Register file faces an operational problem in that while some reorganisations of existing businesses may involve the creation of a new entity that is engaged in new activities, others will not; they may just involve a name change or a change in accountants, resulting in the issuance of a new business registration number. The Business Register does not contain information that allows these distinctions to be made. Therefore, in this study, entry rates calculated from the Business Register include all changes that are defined as a new business therein.

The second source of entry data comes from the Longitudinal Employment Analysis Program (LEAP). The LEAP program produces an administrative file that is also based on the Business Register in that the Business Register is the major source of firm structure and industrial classification for LEAP. LEAP links new births on the Business Register to administrative data on wages paid to employees. Births in this file correspond to births in the commercial sector that eventually report employment earnings. The difference between the LEAP file and the one that is solely based on the Business Register is that the LEAP file uses labour tracking to remove many, but not all, births that are just a result of reorganisation. The editing routines that are used to do so compare firm deaths to firm births in order to examine whether most employees in the former can be found in the latter. If so, it reassigns the identification number of the firm that died to the new firm, thereby removing this form of reorganisation from the calculation of firm births and deaths. While the file removes some false deaths, not all are eliminated. The labour tracking routine does not work well on the smallest firms (generally less than five employees). It also cannot handle all mergers. The advantage of the LEAP file then is that it removes from birth counts some entities that may involve only reorganisations. Its disadvantage is that it may have removed significant events that served to create employment in the sense that the employment would have been lost without these organisational changes.

Annual entry rates from these files are compared in Figure 1 and Table 1 . These are calculated as weighted averages - the sum of all entrants across all industries divided by the sum of all firms in all industries. As expected, firm entry rates are generally highest using the Business Register data (Figure 1). Over the period 1989 to 1997, the entry rate derived from the Business Register averages $18.5 \%$, while the

7. See Baldwin et al. (2000) for an assessment of the importance of reorganisations in this file. 
entry rate from the LEAP administrative file averages $14.5 \%$. These differences also hold across both the manufacturing and the services sector.

Figure 1. Firm entry rate (\% of firms)

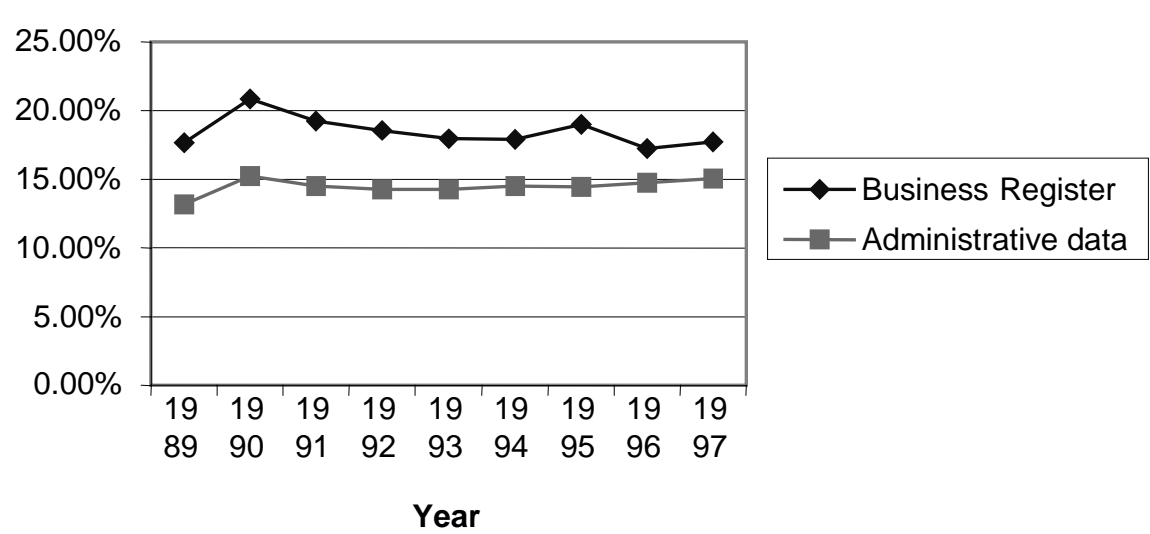

Table 1. Average annual firm entry rates, $1989-97$ (\% of firms)

\begin{tabular}{lcccc}
\hline & All & Manufacturing & Services & Other goods producing \\
\cline { 2 - 5 } Business Register & 18.5 & 16.7 & 18.3 & 18.5 \\
LEAP file & 14.5 & 11.2 & 15.1 & \\
\hline
\end{tabular}

Note: $\quad$ All includes "other goods producing industries" - natural resources, construction as well as manufacturing and services.

The size of the annual entry rates indicates that entry has a dramatic effect on the make-up of the firm population. Between $15 \%$ and $20 \%$ of firms in any year have entered the industry over the past yeareither by undergoing some transformation that entails a substantial change in the nature of the organisation or by suddenly hiring new workers and becoming an employer business.

We also calculate the entry rates using employment in new firms divided by base-period employment. Entry rates using employment give a second metric that takes into account the size of entrants and, in this sense, considers their economic importance. ${ }^{8}$ It has generally been found that entrants are smaller than average and, therefore, employment entry rates are lower than the entry rates calculated using the percentage of firms that have just entered.

Obtaining an accurate measure of employment entry rates is difficult because of problems in determining the size of new firms when data are derived from administrative data. Two quite different methods are used to estimate entry rates in the Business Register and in the LEAP file. In the Business Register, the initial employment size of new firms is meant to be the maximum monthly employment in the first year. It is obtained from the first filings made by the company and is derived from a model that predicts average wages paid on the basis of remittances for pensions, employment insurance and income tax divided by an estimate of average monthly wage derived from survey information. ${ }^{9}$ Implicit in the formula used is the assumption that the first filing only covers one month. If the initial filing of a new company covers more than one month - and unfortunately, new firms may delay filing with the

8. Their economic importance extends beyond their employment size if we recognise the influence that entrants and potential entrants have on the practices of existing firms.

9. The average monthly income includes both full- and part-time workers. 
government for several months - the Business Register file may overstate the true maximum monthly employment in the first year.

On the other hand, in the LEAP file, annual employment is estimated by dividing all wages paid by an entrant over the course of its first calendar year by the average annual income earned by all employees in the same industry - the latter measure is derived by calculating the monthly income for the relevant industry and then multiplying this by the average number of months in a work year. This will underestimate total employment (on a yearly basis) if the new firm is in business for less than a full year. ${ }^{10}$ It will also underestimate employment if income per worker in a new firm is less than the average over the course of a year. One way of correcting for this is to use the second year of employment in entrants, which should cover a full year's operations and to adjust upward the employment of firms that exited before the second year by the average growth rate of the survivors. Unfortunately, this measure will overstate the size of the firm to the extent that it will capture some growth that occurs naturally from first to second year. However, it provides a second estimate that allows a band to be constructed within which the true estimates are likely to fall.

The rates of entry using employment for the Business Register and the two methods of sizing firstyear firms in the LEAP file are provided in Table 2. Since new firms are smaller than average, employment entry rates are generally lower than the firm-numbers entry rates. The Business Register produces an employment entry rate of around 10\%; the LEAP file generates much lower rates - between $2.5 \%$ and $4.0 \%$, depending on whether first-year or second-year employment levels are used to size entry. Differences in the employment rates probably reflect the fact that the BR file includes more mergers than the LEAP file. It is clear from this that methods of sizing employment in first-year firms can have a dramatic effect on entry rates that are calculated using employment.

Table 2. Average firm entry rates, 1989-97 (\% of total employment)

\begin{tabular}{lccc}
\hline & All & Manufacturing & Services \\
\cline { 2 - 4 } Business Register & 11.8 & 9.9 & 11.9 \\
LEAP file (using first-year employment) & 2.5 & 1.2 & 2.8 \\
LEAP file (using second-year employment) & 4.0 & 2.0 & 4.6 \\
\hline
\end{tabular}

\subsubsection{Entry rates using a production survey}

Entry rates may also be calculated from surveys as opposed to administrative files. The third database that is used here to measure entry is derived from a longitudinal file derived from the Annual Survey (Census) of Manufactures - the Longitudinal Manufactures Research File (LRMF). This file covers the universe of plants that are deemed to be manufacturers for the purposes of the manufacturing production survey. The file is derived from a survey sent to large plants and from administrative tax data for small plants. Because the database also links plants to their owning firms, it allows us to distinguish several different forms of entry: $i$ ) entry by a firm that creates a new plant; $i i$ ) entry by a firm that acquires a plant; and iii) entry by firms that switch from one industry to another. It also allows us to measure the plant entry rate - using either plants that are created by new firms or plants that are created by existing firms. This allows us to measure greenfield entry and merger entry separately and to therefore assess the differences in entry rates that occur if mergers are included in some files but not in others.

While this file allows for the calculation of a much more detailed set of entry categories, it suffers the disadvantage that it comes from a population that is less comprehensive than the others. The survey

10. It will also underestimate employment if the new firm has proportionately more part-time workers than the industry average. 
operations division that is responsible for the manufactures survey imposes cut-offs on the Business Register when creating the file that is used for survey operations. This is because the survey operations division is primarily interested in the accuracy of population totals, not in the accuracy of new-firm totals and because there is more uncertainty about the accuracy of classification for small units. Since there is greater doubt about the industry to which new smaller plants and firms should be assigned, many of these are omitted until they reach a certain threshold size. For example, small wholesaling firms will sometimes begin to manufacture products that they see as being necessary to their product line, or they may modify a purchased product to serve a new need, or they may start by selling a final product like a computer and go on to assemble computers from purchased parts. In each of these cases, firms make transitions from one industry to another and rules are adopted by statistical agencies to decide when to reclassify firms. Unfortunately, the smaller the firm, the more difficult it is to ascertain the true industry in which the firm is located and therefore the survey operations division for manufacturing imposes size cut-offs when taking new firms from the register and including them in the production process. Thus, the entry rates derived from the manufacturing file pertain to a population with the smallest firms removed from it. Since entry rates vary inversely by size class, this means that entry rates are expected to be lower from this source. Whether this is much of a problem will depend on the default rule that is used to classify difficult or uncertain cases. If the default rule is to classify uncertain cases in the Business Register as manufacturing firms, then the former will have a much larger population than the survey operations division.

Several different entry measures for the manufacturing sector using the LRMF file are provided in Table 3 for the period 1989-97. ${ }^{11}$ The first considers all new plants, some of which originated in new firms, some of which are created by existing firms. On average, some $8 \%$ of all plants are new, accounting for $3 \%$ of employment. The second measure captures the entry that occurs because firms that are new to manufacturing enter by building new plants. We call this "de novo greenfield entry", because it involves the creation of a new (greenfield) plant and it involves a firm that is completely new to the manufacturing sector (de novo entrants). ${ }^{12}$ Most of the new plants fall in this category since this category's entry rate is $7 \%$ and the employment in these plants is $2.1 \%$ of total employment on average. The latter is quite close to the annual employment entry rate derived from LEAP for manufacturing.

The third is the entry rate of firms that entered a four-digit industry (but may not have been new to the manufacturing sector as a whole) by building new plants. This rate is the sum of both de novo and existing-firm greenfield entry. It captures the latter because it includes firms that are already in one manufacturing industry but that open up a new plant in another four-digit industry. At some $7.8 \%$ of plants and $2.6 \%$ of employment, this is larger than the first measure ( $7.0 \%$ and $2.1 \%$, respectively), since it allows for entry by firms that already exist in another industry.

The fourth measure captures entry to manufacturing via acquisition of a plant. This accounts for only $0.8 \%$ of plants on average, but $3.2 \%$ of employment. Similar to our results for the 1970s (Baldwin, 1995), the employment annual rate of entry by acquisition is just as large as the employment rate of de novo entry. Databases than cannot distinguish greenfield entry from merger entry will generate employment entry rates that are larger than those that just use greenfield entrants. The size of the difference will depend upon how many firms enter by merger.

The fifth measure expands the definition of an acquisition entrant to include any firm that is new to a four-digit industry. It will be larger than the fourth measure to the extent that acquisition entry takes place by existing manufacturing firms. This acquisition entry rate is considerably larger, at $2.6 \%$ of plants annually and $6 \%$ of employment, thereby demonstrating that much of the entry that occurs via acquisition

11. Each of these is a weighted average of the annual entry rates over the period - the sum of entrants over the sum of existing plants.

12. The firm may have existed outside the manufacturing sector. 
is done by firms that are already in manufacturing. Once more, the size of this phenomenon points to the importance of purging entry databases of mergers if the true effect of greenfield entry on employment is to be calculated.

Table 3. Average entry rates, 1989-97 from Census of Manufacturers

\begin{tabular}{llcc}
\hline & Category & $\begin{array}{c}\text { Manufacturing } \\
\text { (\% of total plants) }\end{array}$ & $\begin{array}{c}\text { Manufacturing } \\
\text { (\% of total employment) }\end{array}$ \\
\hline 1 & New plant & 8.1 & 3.0 \\
2 & New manufacturing firm new plant & 7.0 & 2.1 \\
3 & New firm to four-digit via new plant & 7.8 & 2.6 \\
4 & New firm acquired plant & 0.8 & 3.2 \\
5 & New firm to four-digit via acquisition & 2.6 & 6.0 \\
6 & Entry new to manufacturing via both greenfield & 8.4 & 5.3 \\
7 & and merger & & 8.5 \\
\hline
\end{tabular}

The sixth entry rate is the sum of entry by firms that either create a new plant or acquire an existing plant, but defines entry as a new firm to manufacturing as a whole. The last is an all-inclusive measure that includes both greenfield entry and reorganisation but that defines entry as a firm that is new to a four-digit industry rather than to the manufacturing sector as a whole. It is evident that the two total entry rates presented here are two to three times larger than the pure greenfield entry rates. The highest entry rate, that includes both greenfield entry and acquisition entry, and counts both de novo and existing manufacturing firms as entry to any four-digit industry, provides a $10 \%$ annual rate for firms and $8.5 \%$ for employment over the 1989 to 1997 period. It should be noted that the employment entry rate derived here is quite close to the employment entry rate derived from the Business Register and suggests that the latter's employment entry rate contains a large number of mergers.

The importance of distinguishing between entry by merger and entry by new plant creation is evident. Entry rates that include a substantial portion of merger entry will not differ greatly from those that are capturing only greenfield entry, when measured in terms of number of new entrants. They will, however, differ when the importance of entry is being measured with employment.

Any international comparisons must therefore be cognisant both of the sources and the methods that are used to measure entry. These comparisons should be cognisant of the trade-offs that exist in the choice of firm-based as opposed to employment-based rates. Firm-based rates are less likely to be affected by the failure to exclude merger and reorganisation activity, but they are more likely to be affected by the size of the population that is used to measure entry. If a data file fails to purge entry by merger, its employmentweighted estimates of entry will be quite a bit higher than if it includes only greenfield entrants; if it cuts part of the smaller population out, then its firm-based entry rates will be lower.

\subsection{The maturation of entrants}

Annual entry rates, by themselves, may not allow us to assess the contribution that entrants make in the longer run. The cumulative effect of entry in the longer run will be measured here as the percentage of firms and employment five or ten years from now that have been born in the interim and that are still in existence. To estimate this, we need to examine how the effect of successive cohorts (years) of entrants add up over time. To do so, we need a profile of surviving entrants for each cohort.

Entry may be so difficult that all entrants disappear within a year. In this case, the importance of entry is adequately summarised with annual entry rates. The cumulative rate of entry of several years' entrants 
will just be the annual rate of entry. For example, if the annual rate of entry is $6 \%$ but all entrants die within a year of birth, then five years from now, only $6 \%$ of firms will be new and they will all have been born in the last year of the five-year period. However, if entrants disappear at a slower rate, then the effect of entry in any one year is spread out over future years, and estimating the cumulative impact of entrants requires that the impact of several cohorts (years) of entrants be added together. For example, if no entrants die, a $6 \%$ annual rate of entry would translate into a cumulative five-year rate of around $30 \%$. Since neither extreme is likely in practice (neither all entrants die nor do all survive), the cumulative rate of entry lies somewhere between these points. Whether it lies closer to the lower or the upper bound depends on the rate at which new firms die or, conversely, the rate at which they survive.

In order to examine the success of entrants, we calculate their survival rates, that is the percentage of the original group of entrants that survives for one year, three years, five years and nine years. The resulting survival rates are included in Table 4 . These rates are calculated using both the Business Register file and the administrative LEAP file. Both files indicate that new firms fail at very high rates. In the case of the group of entrants that are picked up by the Business Register, more than $25 \%$ die in the first year, over $50 \%$ are dead by their fifth year, and $80 \%$ by their ninth year. The survival rates for the new firms found in the Business Register are slightly lower than those in the LEAP administrative file. Since the difference in the entrants included in the two files basically involves firms with name and organisational changes, we infer that the latter types of new firms in the Business Register are particularly vulnerable to failure - which could either occur as a result of closedown or merger with other entities.

Table 4. Survival curves (\% of entrants still alive at different ages)

\begin{tabular}{lcccccc}
\hline Year & $\begin{array}{c}\text { All } \\
\text { (BR) }\end{array}$ & $\begin{array}{c}\text { All } \\
\text { (Admin) }\end{array}$ & $\begin{array}{c}\text { Manufacturing } \\
\text { (BR) }\end{array}$ & $\begin{array}{c}\text { Manufacturing } \\
\text { (Admin) }\end{array}$ & $\begin{array}{c}\text { Services } \\
\text { (BR) }\end{array}$ & $\begin{array}{c}\text { Services } \\
\text { (Admin) }\end{array}$ \\
\hline 1 & 73.2 & 76.9 & 75.7 & 79.9 & 74.5 & 78.1 \\
3 & 44.3 & 48.1 & 47.9 & 52.9 & 45.6 & 48.7 \\
5 & 31.5 & 34.7 & 36.0 & 40.5 & 32.7 & 34.9 \\
9 & 18.5 & 23.7 & 23.1 & 30.4 & 19.1 & 23.1 \\
\hline
\end{tabular}

The high exit rates of new firms over their early years means that longer-run entry rates that are calculated using the number of firms that survive longer than one year are lower than the annual rates. We present in Table 5 the five-year cohort entry rates, which are defined as the number of new firms as of period $t$ that last until period $t+5$ divided by the population in period $t \cdot{ }^{13}$ This can also be calculated as the product of the annual entry rate and the five-year survival rate. Running between 5\% and 6\%, these fiveyear entry survival rates are considerably lower than the annual entry rates of between $15 \%$ and $20 \%$. Viewed from this perspective, entry is still important but it is no longer as enormous as the annual or oneyear entry rates. More importantly, the difference between the result produced by the different data files is much smaller. The differences in the cohort survival rates are less than $1 \%$, compared to the $4 \%$ that separated the two entry rates in Table 1 . Definitions of newness matter more for measuring the amount of short-run entry than they do for measures of long-run entry.

Table 5. Average five-year firm entry rates, 1989-97 (\% of firms)

\begin{tabular}{lccc}
\hline & All & Manufacturing & Services \\
\hline Business Register & 5.6 & 6.0 & 5.7 \\
LEAP file & 5.0 & 4.5 & 5.3 \\
\hline
\end{tabular}

13. As was the case for Table 1, these are calculated as weighted averages of all the underlying industries. 


\subsection{The evidence on the effect of long-run entry on employment}

We are also interested in measuring the contribution of entrants to employment growth in the long run. The contribution of new firms to total employment is determined by the rate at which they enter an industry, their rate of survival and the rate at which the employment in survivors grows.

Many firms are born each year. A large share of these die but a number survive and grow. Because of this, the long-run employment entry rate of a particular cohort will not decline at the same rate as the longrun firm survival rate discussed in the last section. The survivors achieve enough growth that the group of survivors as a whole makes an important contribution to employment - especially when groups of entrants in successive years are added together.

Table 6. Employment short- and long-run entry rates, average 1989-97

\begin{tabular}{lcc}
\hline Year & $\begin{array}{c}\text { Using second-year } \\
\text { employment for sizing }\end{array}$ & $\begin{array}{c}\text { Using first-year } \\
\text { employment for sizing }\end{array}$ \\
\hline Column I & Column II & Column III \\
\hline Panel A: Using employment in birth year & & $2.5 \%$ \\
Year 1 & $4.0 \%$ & $2.2 \%$ \\
Year 3 & $4.0 \%$ & $1.6 \%$ \\
Year 5 & $1.9 \%$ & $1.3 \%$ \\
Year 9 & $1.5 \%$ & $1.3 \%$ \\
& $1.0 \%$ & \\
Panel B: Using employment in subsequent year & & \\
Birth year & & $2.5 \%$ \\
Year 1 & & $3.5 \%$ \\
Year 3 & $4.0 \%$ & $3.2 \%$ \\
Year 5 & $3.5 \%$ & $2.9 \%$ \\
Year 9 & $3.2 \%$ & $2.7 \%$ \\
\hline
\end{tabular}

In order to illustrate the effect of entrants on employment, we make use of the LEAP file and the two different methods of sizing the first-year employment of new firms (Table 6). The first method (column II) uses second-year employment to capture the full-year employment for year one. The second (column III) uses first-year employment to capture the full-year employment for year one. We calculate the long-run contribution of entrants in two stages. In Panel A, the entry rate is measured as the employment of firms as of year $\mathrm{t}$ that survive to $t+j$ divided by total employment in year $t$. This is equivalent to the long-run firm entry rate - and tells us how much of the first-year employment remains after $j$ years. For example, using second-year size to measure entry employment, employment in entrants as of their first year is $4 \%$ of total employment on average. Because of deaths of entrants, by year 9 a substantial amount of this first-year employment disappears and only $1 \%$ of the original employment is left. However, using remaining firstyear employment will understate the long-run impact of entry since many of the remaining entrants will grow from their first-year size. In Panel B, we calculate the long-run employment entry rate as the employment in year $t+j$ of entrants that survive, divided by the initial employment of all firms in year $t$. The employment of surviving entrants in year $t+j$ will be greater than initial employment in year $t$ if the survivors have grown. When this growth factor is considered, the long-run entry rate by year 9 increases from $1 \%$ to $2.6 \%$. This also happens when we consider the alternate method of sizing first-year firms that can be used in the LEAP database - column III. In this case, long-run entry by the $9^{\text {th }}$ year increases from $1.3 \%$ to $2.7 \%$. It should be noted that while there are considerable differences in the one-year average entry rates calculated from the two sizing methods (4\% versus $2.5 \%$, using second-year and first-year sizing methods, respectively), there is virtually no difference in the nine-year rate $(2.6 \%$ and $2.7 \%$, using the 
same two sizing methods). Once again, adopting a longer-term horizon to estimate entry reduces the likelihood that the results will be heavily dependent on the database used.

The cumulative effect of successive cohorts can be large. The cumulative importance of new firms can be measured by the percentage of any population that is made up of recent entrants - firms that have entered within the last five or ten or 20 years. If all entrants disappeared almost instantaneously, then the importance of firms that have entered today should not differ substantially from the short-run rates quoted above. This is not the case.

Entry results in substantial renewal of the population. Figure 2 plots the cumulative effect on employment of adding together a number of cohorts - using the post-entry performance outlined in Table 6, Column 1, Panel B. It plots the cumulative effect of entrants going back one year, two years, three years, to 20 years. The results in this figure were projected from the data in Table 6 using regression analysis over a 20 -year time horizon. ${ }^{14}$ If we consider only one cohort, entry will account for $4 \%$ of employment; two cohorts provide 7.5\% (4\% from the cohort that has just been born and $3.5 \%$ from the cohort that is one year old and has already experienced some attrition). By expanding the number of entry cohorts considered, the importance of entrants increases in a non-linear fashion and begins to flatten out markedly by 20 years, when it reaches about $50 \%$. It is this process that leads industries to reinvent themselves. Competition, as manifested by the entry and exit process, gives rise to a fundamentally different landscape.

\section{Figure 2. Cumulative effect of entry on employment}

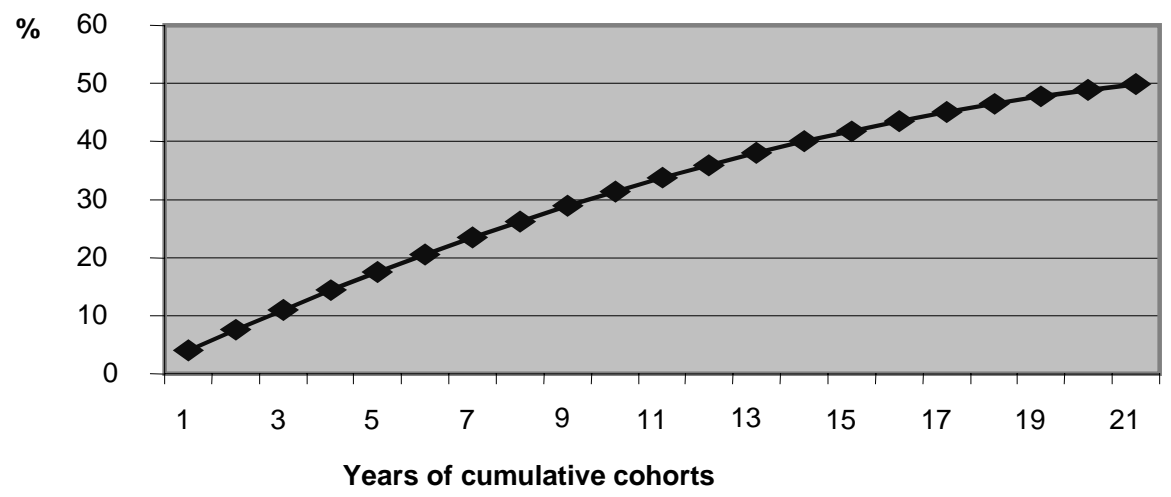

Of course, measuring the point at which an entrant should no longer be classified as a new firm and should join the incumbent class is an important issue. As firms mature, they offer different threats and challenges to incumbents. One way of answering this question is to ask when the hazard rate of new firms approaches that of incumbents. Baldwin et al. (2000) find that the hazard rates of new firms, when measured in their teen years, is still above that of incumbents; but, by their fifth year, substantial differences in the effect of certain covariates associated with the rate of exit have disappeared. Hazard rate differentials across geographic regions and industries are far more prevalent in entrants that are one and two years old than they are for entrants that have managed to make it through their first five years.

While the cumulative estimated profiles presented in Figure 2 depend upon a particular database and a particular set of results that are affected by the nature of the decade that generated them, the exercise is nevertheless useful. It approximates what actually takes place. In 1995, some $70 \%$ of the firms in existence in the LEAP file had been born since 1983 and these firms accounted for 26\% of all jobs in 1995.

14. This procedure assumes a static population with no exits from sources other than from entrants. 
When the same exercise, as illustrated in Figure 2, is performed using the entry employment data for manufacturing, the cumulative effect of entry is $18 \%$ of employment after ten years and $36 \%$ of employment after 20 years. This is very close to the actual results using the LRMF file. On average, over $39 \%$ of all plants in existence in the average Canadian manufacturing four-digit industry in 1980 had entered since 1970; these plants accounted for about 16\% of shipments (Baldwin, 1995, p. 409). Ten years later in 1990, over $61 \%$ of all plants in existence belonged to firms that were new since 1970; these plants accounted for about $34 \%$ of shipments. Entry is the force that brings brand-new plants and firms into an industry. It results in a substantial change in the participants in an industry.

\subsection{A comparison of Canada to the United States}

Because of the considerations outlined above, estimates of the size of entry that emerge from different countries cannot be easily compared. However, there is one carefully constructed set of comparisons that have been done for Canada and the United States, using manufacturing data collected in a similar manner using similar definitions (Baldwin, Dunne and Haltiwanger, 1998). We make use of these data to compare the quantitative importance of entry in the United States and Canada.

A strong resemblance between the entry process in Canada and the United States emerges when entry rates are compared over similar time periods with similar levels of aggregation and similar definitions of populations. ${ }^{15}$ Short-run annual entry rates to the manufacturing sector in aggregate are quite similar when employment entry rates are calculated. The annual entry rates to manufacturing as a whole from 1972 to 1986 for selected years where data were available for both countries, averaged about $2.4 \%$ for Canada and $1.9 \%$ for the United States (Baldwin, 1995, p. 127). When calculated over five-year periods (1972-77, and 1977-82), the Canadian average across two-digit industries was $10.9 \%$, while the US average was $11.3 \%$ (Baldwin, 1995, p. 137). It is also important to note that, in both countries, the death rates were quite similar to the birth rates.

More recent data also show strong similarities. Comparisons can be made using Canada's LEAP database and the US Census Longitudinal Business Database Prototype (derived from the Standard Establishment Statistical List). Entry rates are calculated from both databases as those firms who are new and who survive one year. Sizing is done on the basis of the second year of existence. The entry rates are thus broadly comparable to those calculated using LEAP second-year employment. The comparisons show that the sum of the annual entry and exit rates calculated using number of firms for the period 1989-94 averaged $21.7 \%$ in Canada and $20.3 \%$ in the United States for the business sector. ${ }^{16}$ The sum of the entry and exit employment rates in manufacturing is $2.5 \%$ in each country; it is $5.0 \%$ for services in Canada and $4.7 \%$ for services in the United States (OECD 2001, Annex 1, Table 7). Given the variances in the error rates that arise in measuring entry outlined in previous sections, aggregate turnover rates in Canada and the United States are indistinguishable.

These rates need to be set in context. Entry is not the only process that leads to the turnover of the firm population. Growth and decline in the incumbent population is also occurring. At any point in time, the population of enterprises can be divided into those who are growing and those who are declining. Job turnover is measured as the sum of all employment increases in those growing (job growth) and the sum of the change in employment in those declining (job loss). The importance of entry and exit can be calculated as the share of job growth that is accounted for by entry, or the share of job decline that is accounted for by exit. When this is done using comparable manufacturing databases for Canada and the United States, the results are quite similar. For year-to-year changes from 1970 to 1985, job creation due to entry in Canada

15. See Baldwin (1995, Ch. 6).

16. This excludes agriculture and community services. 
averaged $27 \%$ of the total job increase; in the United States, it averaged 21\% (Baldwin, 1995, p. 126). Calculated over two comparable five-year periods (1972-77, 1977-82), entry accounted for $45 \%$ of job growth in Canada and $44 \%$ in the United States. As the length of period over which entry is calculated grows, the importance of entry increases as entry cohorts accumulate.

Despite fundamental differences in the size of the Canadian and US economies, the competitive pressures that develop from entry and exit are quite similar. Canada has a smaller economy. It has higher levels of unionisation. It is an economy that is more open. It has markets that are smaller and more concentrated. It has a higher degree of foreign ownership. Yet, despite these differences, it exhibits about the same degree of turnover from entry and exit as does the United States.

\subsection{A comparison of entry in the goods and services sectors}

In the remainder of this paper, we concentrate on how entry differs across size classes and between the goods and services sectors. The data here provide a concrete illustration of many of the points made in previous sections. They also allow us to compare differences across size classes and across two major sectors - goods $v$ s. services.

Entry is an experimental process involving a considerable investment in knowledge by new firms how to organise, how to produce, how to invest, how to market, how to manage. This knowledge can be acquired before entry through investments in knowledge. Additional knowledge can be acquired after entry, but at a cost - the cost associated with failure. Investing in post-entry as opposed to pre-entry information will be pursued more extensively in situations when the cost of knowledge acquisition via experimentation is lower - where exit due to failure involves lower costs. In industries where this is true, we would expect higher rates of both entry and exit. More firms will test out the market when experimentation is less costly. Since goods industries like manufacturing involve large-scale firms and substantial amounts of capital goods that contain a larger portion of sunk costs, experimentation costs are high here and entry rates are expected to be lower than in service industries that involve smaller units on average and where sunk costs make up a smaller proportion of total investment.

This section compares the goods and services sectors - two sectors that differ in their post-entry costs of experimentation. Firms in the goods industries are more capital intensive. They use more machinery and equipment per worker than do firms in the services sector. Firms in goods industries therefore face higher costs of experimentation. We might therefore expect the two to differ in terms of their use of entry as a form of experimentation. Even if the long-run entry rates of the two are similar, the short-run rates will differ.

For this section, we make use of a sample of all entrants in the LEAP database who were born in the years 1984, 1985 and 1986 and focus on their survival rate in 1994. On average, the group of cohorts was nine years old if they survived to 1994. This was a period of strong growth in the Canadian economy, a period during which entrants might have been expected to do well.

The contribution of new firms is determined by the rate at which they enter an industry, their rate of survival and the rate at which the survivors grow. Large numbers of firms are born each year and many of these die. Nevertheless, a sufficient number of these new firms achieve enough growth to ensure that the group of survivors as a whole makes an important contribution to employment at any one point in time especially when groups of entrants in successive years are considered. The nature of the process, however, differs across the goods and the services sectors. Table 7 contains both short- and longer-run entry rates calculated using number of entrants and employment in new firms. Columns 2 and 4 contain the average 
one-year entry rates for the three entry cohorts, calculated using number of firms and employment ${ }^{17}$, respectively; column 3, the entry rate if only the surviving entrants are used (the survivor entry rate); column 5, the surviving employment entry rate if only first-year employment of the surviving entrants is used; column 6, the surviving employment rate if the 1994 employment of the surviving entrants is used.

Table 7. Entry rates $\mathbf{- 1 9 8 4 - 8 6}$ cohorts from the LEAP file

\begin{tabular}{|c|c|c|c|c|c|c|}
\hline Industry & Size class & $\begin{array}{l}\text { Entry rate } \\
\% \text { of firms }\end{array}$ & $\begin{array}{l}\text { Survival entry } \\
\text { rate to } 1994 \\
\% \text { of firms }\end{array}$ & $\begin{array}{c}\text { Entry rate } \\
\% \text { of } \\
\text { employment in } \\
\text { year of birth } \\
4\end{array}$ & $\begin{array}{l}\text { Survival entry rate } \\
\text { to } 1994 \\
\% \text { of employment } \\
\text { in initial year } \\
5\end{array}$ & $\begin{array}{c}\text { Survival entry rate } \\
\% \text { of } 1994 \\
\text { employment } \\
6\end{array}$ \\
\hline \multirow[t]{4}{*}{ All } & 0 to 9 & 20.6 & 3.9 & 10.4 & 2.1 & 6.9 \\
\hline & 10 to 24 & 6.9 & 2.6 & 3.5 & 1.6 & 4.3 \\
\hline & 25 to 200 & 5.4 & 2.8 & 3.2 & 1.8 & 3.7 \\
\hline & Total & 18.9 & 3.8 & 5.8 & 1.9 & 4.9 \\
\hline \multirow[t]{4}{*}{ Goods } & 0 to 9 & 15.9 & 3.8 & 8.2 & 2.2 & 8.5 \\
\hline & 10 to 24 & 6.0 & 3.0 & 2.9 & 1.4 & 5.2 \\
\hline & 25 to 200 & 4.1 & 2.2 & 2.5 & 1.5 & 3.0 \\
\hline & Total & 14.3 & 3.7 & 3.8 & 1.7 & 4.7 \\
\hline \multirow[t]{4}{*}{ Services } & 0 to 9 & 21.6 & 3.9 & 10.8 & 2.1 & 6.6 \\
\hline & 10 to 24 & 7.0 & 2.5 & 3.6 & 1.7 & 4.0 \\
\hline & 25 to 200 & 5.9 & 3.1 & 3.5 & 2.0 & 4.0 \\
\hline & Total & 19.9 & 3.8 & 6.3 & 2.0 & 5.0 \\
\hline
\end{tabular}

Over the 1984-86 period, new firms averaged 18.9\% of the population of businesses (Table 7, column 1). Entry is higher in the services sector $(19.9 \%)$ than in the goods-producing sector $(14.3 \%){ }^{18}$

The importance of entrants differs considerably by size class. The smallest size class (0-9 employees) has the largest proportion of firms that have just entered; on average, $20.6 \%$ of firms in this class were born in the years 1984-86 (Table 7, column 2). Entry rates are lowest for the largest size class (5.4\%). Service industries have higher entry rates than do goods industries for each size class.

The importance of entry is somewhat less when calculated using employment size, since entrants are smaller than the average firm. If we calculate the rate of entry using employment in their first reporting year, employment in entrants is $5.8 \%$ (Table 7 , column 4 ).

Life for new firms is difficult and many do not have the skills to survive. At year 9, the survivors in the goods sector have fallen to $20 \%$ of the original number of entrants. The survival rate for firms in the services sector is lower than for goods-producing firms (19\% as opposed to 26\%). Those firms who start smaller are particularly susceptible to failure. The survival rate is lowest (19\%) for entrants that started with fewer than nine employees. It is $52 \%$ for firms with more than 24 employees.

If entry is calculated not as the proportion of firms that are new each year (the instantaneous entry rate), but as the proportion that last until 1994 (the survivor entry rate), the rate of entry is much smaller. For example, some $19 \%$ of firms are new each year (Table 7, column 2), but only $4 \%$ of the population are new firms who will survive past early childhood until age nine (Table 7, column 3 ). While entrants account

17. All calculations in this section size entrants using first-year rather than second-year employment.

18. For this exercise, construction has been included in the services sector. The entry rate is calculated as the sum of all entrants over the years 1984-86 in the commercial sector. 
for about $6 \%$ of employment each year (Table 7, column 4), only $2 \%$ of jobs initially are in those firms who will survive to their teen years (Table 7, column 5).

The instantaneous entry rates are higher in the service industries than the goods industries, both in terms of number of entrants and employment. In that sense, the services sector is subject to greater volatility from new competition. In contrast, while goods industries are harder to enter than service industries, entrants are better able to survive the vicissitudes of early childhood in goods than in service industries. These two tendencies offset one another so that the net effect is essentially zero: there are few differences in the survivor entry rates in the goods (3.7\%) and services $(3.8 \%)$ sectors. Entry is a phenomenon with about equal importance if the groups that are unsuccessful and exit are removed from the calculations (Figure 3). This means that, for each successful entrant, there is more experimentation via entry in the services than the goods sector.

Figure 3. Instantaneous vs. survivor entry rates

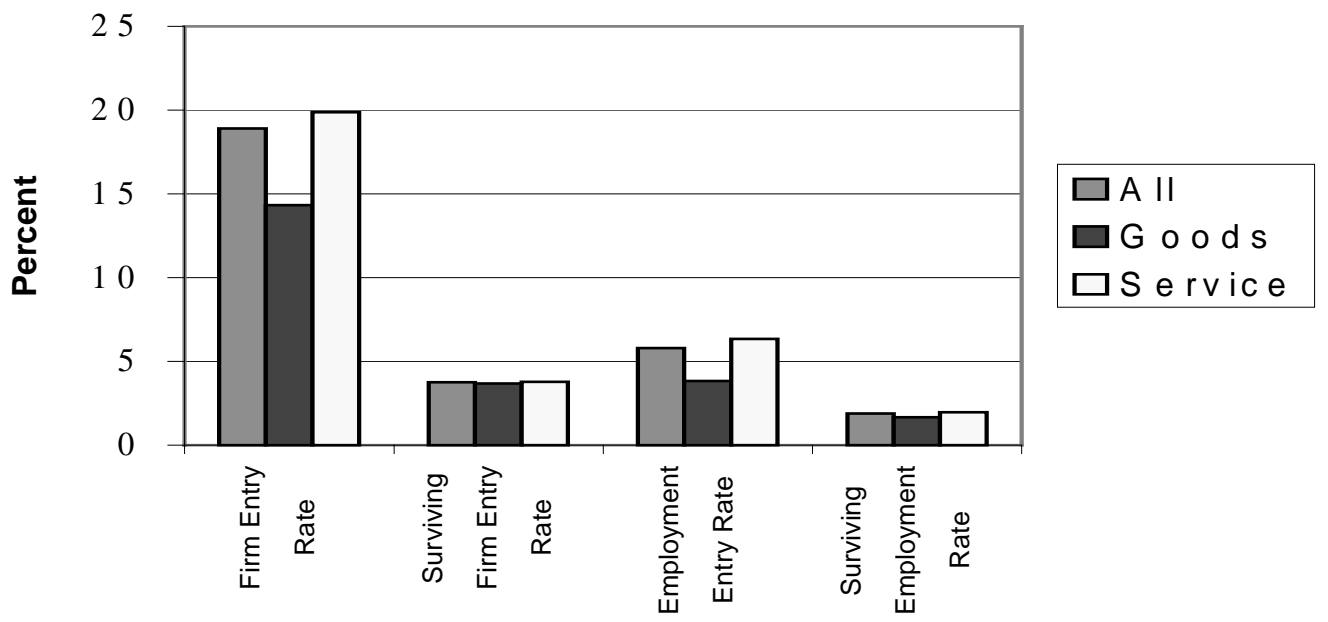

While a large percentage of new firms die, the remainder grow. The relative importance of a group or cohort of entrants depends upon whether the employment growth in the survivors offsets the loss of employment due to the demise in the overall number of firms in each entry cohort. The ultimate importance of an entry cohort can be determined by calculating their employment at a later stage in life and comparing it to total employment in all entrant firms in their year of birth. When this is done, the size of the survivors is impressive. Initially, the group of entrants accounted for 5.8\% of employment (Table 7, column 4). Only $1.9 \%$ of employment is in entrants that will survive to their ninth year - but the employment of those who do survive will equal $4.9 \%$ of initial-year employment (Table 7, columns 5 and 6, respectively). Thus, while those that survive make up a small proportion of those who enter, their growth is almost enough to maintain the importance of the cohort.

To set the performance of the survivors in context, we compare the total number of jobs created by all entrants in the year of birth, the number of jobs in the survivors in their birth year and finally the number of jobs in survivors in 1994 for the 1984, 1985 and 1986 entry cohorts (Figure 4). Growth in the goods industry in the late 1980s is so robust that surviving entrants manage to increase the number of jobs in the cohort in 1994 above those in the birth year - despite the exit of new firms. ${ }^{19}$ In the services sector, growth is not sufficient to offset the exit of some of the cohort in their early infancy and the total employment in

19. See Baldwin (1996) for an examination of how this changes over different periods. 
the entry cohort declines. It is noteworthy that an entry cohort's effect in the goods sector wears off less quickly than in the services sector, because survivors grow more rapidly. ${ }^{20}$

Figure 4. Employment progress of entry cohorts

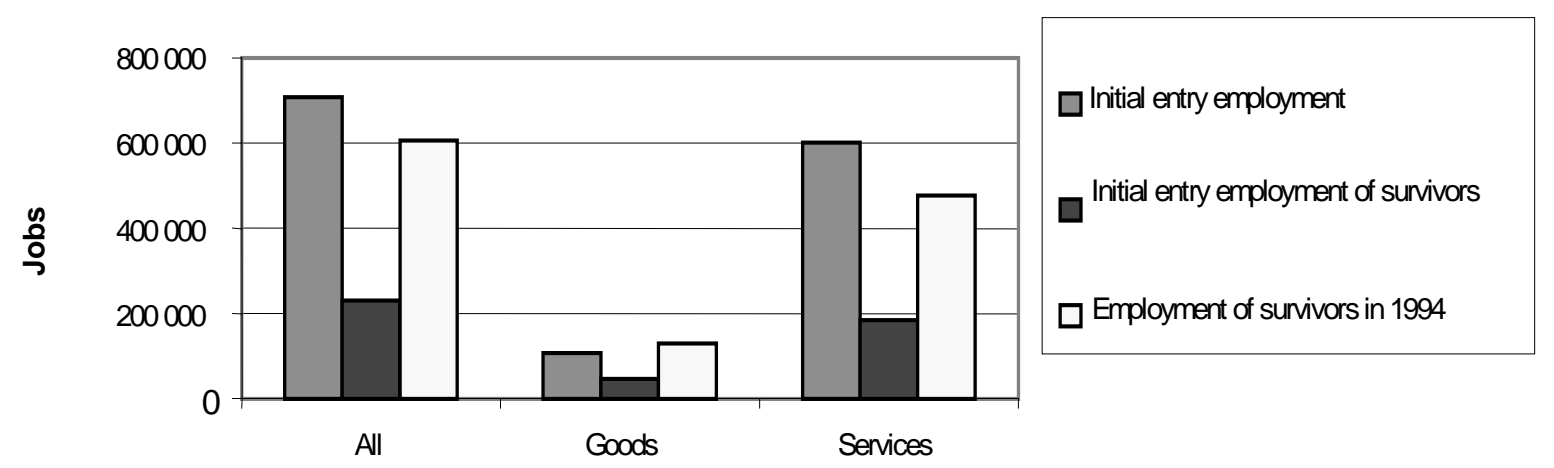

Of course, much like the analysis presented in the previous section, considering the joint effect of several years of recent entrants magnifies the importance of the population of firms that have recently entered. As already indicated, some 70\% of the firms in existence in 1995 had been born since 1984 and these firms accounted for $26 \%$ of all jobs.

\section{Conclusion}

This paper has attempted both to measure the importance of entry and to note the sensitivity of the estimates to the use of different databases. Studies that attempt to assess the importance of entry need to be cognisant of the methods that are used to create the longitudinal databases used for measurement. Entry rates differ depending on the definition of a new firm used, the comprehensiveness of the databases used to measure entry, and the way in which first-year firms are sized.

This study argues that short-run entry rates calculated using number of firms is highly sensitive to the comprehensiveness of the databases used to measure entry, but less sensitive to this factor when employment-weighted estimates are used. Differences in the results produced by different databases are less when long-run rates are used or when annual rates are averaged over several years to smooth out the idiosyncrasies that exist in the microeconomic databases used to measure entry. The percentage of firms who enter and survive to a point in the future is quite similar across the databases used here. Entry statistics that measure the importance of the phenomenon with employment are less susceptible to idiosyncratic cutoffs but are more sensitive to whether merger entry is or is not included. In Canada, there is a substantial amount of annual turnover due to control changes; entry rates that include most mergers will be much higher than those that are essentially purged of this form of turnover.

The entry measures derived herein show that the dynamic process that brings new firms into an industry and forces old firms out of industries dramatically reshapes the industrial landscape. On an annual basis, a large number of firms attempt to break into markets each year. In Canada, somewhere between $15 \%$ and $20 \%$ of all firms are new each year - with slightly higher percentage in services than in manufacturing. The impact on employment of a single year's entry cohort is less, since entrants are on average smaller than the average firm in an industry. Depending on how the size of new firms is measured,

20. If we define the entrants' size as their employment in the first full year after birth, the employment of the goods cohort declines slightly but the effect of entrants still wears off less quickly in the goods than the services sector. 
firms that have entered in the preceding year by building new plant account for between $2 \%$ and $4 \%$ of employment on average.

On the other hand, if we examine entrants who survive for five years, firm entry rates are lower. Using number of firms, the surviving entry rate ranges from $5 \%$ to $6 \%$; on the other hand, five-year employment entry rates are not much lower than one-year rates; the surviving entry rate for new firms that enter by building new plants is about $2.5 \%$ for the economy as a whole.

The impact of entrants increases if it is measured not just in terms of firms that had entered in the previous year but taking the cumulative effect of five or ten years of new firms. Not all entrants will survive to be counted in such an estimate - but a large enough group will do so to ensure the cumulative effect of entry grows as the time period used to measure the phenomenon increases. In the manufacturing sector, ten years of entrants account for some $16 \%$ of shipments; 20 years of entrants account for about $34 \%$ of shipments. These long-run estimates are equally high in the services sector.

In conclusion, entry is important for two reasons. First, a large percentage of firms in any period are recent entrants and, while many new firms do not survive, some do and grow. Taken together, successive cohorts of entrants, both the more and less mature, account for a significant proportion of output. 
DSTI/DOC(2002)3

\section{APPENDIX A}

\section{CHOICE OF DATABASE FOR RESEARCH PURPOSES}

Three different databases were used in this paper in order to provide interested readers with an idea of the sensitivity of estimates of entry and exit rates to the use of alternate data sources.

Understanding the magnitude of the differences in entry and exit rates that can be produced by different databases is particularly important for those making international comparisons. These comparisons are often used to infer differences in the dynamics of different economies, especially differences in the degree to which the environment of different economies are more or less conducive to the type of experimentation and incorporation of new ideas that are so often associated with new firms.

If differences in cross-country estimates presented in international comparisons do not truly represent differences in the propensity of new-firm creation, then these international comparisons are misleading.

In this paper, we have made use of three Canadian databases that come from different sources, none of which is perfect for entry studies. The LEAP file (an acronym for the Longitudinal Employment Analysis Program) is based on payroll data coming from tax declarations of employers and administrative data on the structure of firms. While comprehensive in the sense that it comes from an administrative source, it requires several transformations before it can be used, each of which can produce errors. First, payroll data coming from payroll units has to be consolidated into firms. Secondly, false deaths and births have to be removed by labour tracking. Finally, payroll data have to be transformed into an employment equivalent by dividing by a wage rate that is derived from a survey source.

The second data source - the Business Register (BR) - is the database that is maintained by the Statistical Agency as the basis for all of its business surveys. However, this register is not maintained as a virtual record of all firms in the economy. Various administrative sources are used to add new firms to the register, but some firms may not be caught immediately, and some that are added to the register may not be new. Some enterprises change their names or legal status and can be caught anew in the administrative sources when this happens. The data on the register with regards to employment and revenues, which is essential to sizing the new unit, may also be inaccurate. This can occur because of problems in sizing new units that are less than a year old. If the first month's data for a firm covers more than one month, simply multiplying by twelve will not give an accurate estimate of the annualised size of the firm. More importantly, while it is less expensive to note the appearance of a new unit, it is more difficult to profile the unit and add data on wages or revenue. This means data on the size of new entrants are less accurate.

The final source of data - the Longitudinal Manufactures Research File (LRMF) - is the richest. It offers many more variables than the other sources - with data on employment, shipments, materials, value added, wages of production workers, salaries of non-production workers and energy consumption. As such, it is more useful for studies that ask how productive new entrants are. But the Manufactures data suffer from the fact that the manufactures division does not use the entire universe of all manufacturing firms in the Business Register. The Annual Survey of Manufactures (ASM) chooses a smaller universe than that covered in the Business Register. Very small firms on the Business Register are omitted from the sample 
universe used for the Manufactures file. The manufactures division uses a reduced population that it feels accurately measures totals for output and employment. Unfortunately, budget cutbacks have meant that in some years the proportion of small manufacturing firms covered in the ASM falls. This is particularly the case in the early 1990s. In the version reported here, we define entry as the birth of firms that are entirely new to manufacturing as a result both of greenfield entry and of merger entry. We also report an entry rate that just captures new firms that have all new plants in the year of the firm's entry - what is referred to here as the greenfield entry rate.

The body of the paper has compared the entry rates derived from each of these sources. Table A1 contains average annual entry rates for the period 1989-97 for the three different databases. Table A2 contains the annual exit rates for same period. In each case, the entry and exit rates are reported at the individual industry level using a set of industry classifications used by the OECD.

As expected, the firm average entry rates are lowest for the LMRF database, at 7-9\%. The LEAP entry rates are next, at about $12 \%$, and include many more small entities. The BR entry rates at around $18 \%$ on average are highest since they contain both greenfield entry and various forms of reorganisations. The range for these entry rates is about $10 \%$ between the lowest and the highest. This suggests that a fairly large confidence interval needs to be used for cross-country comparisons of firm-based entry rates. The same conclusions are drawn from the exit rates provided in Table A2.

In contrast, there is much less of a difference between the employment rates from the various sources. The employment entry rate using the LMRF is $5.6 \%$, but it falls to $2 \%$ if we exclude mergers. This compares to $1.3 \%$ derived from the LEAP file and the method that uses first-year employment to size entrants. Using second-year employment would increase the LEAP rate to around the rate produced by the manufactures file. By way of contrast, the BR employment entry rate is about five times as large, at around $10 \%$ on average, but it is probably biased upwards by the sizing method used.

The longer-term entry and exit rates that arise from comparing 1989 and 1997 are tabulated in Tables A3 and A4. For firm-based entry rates, we once more find that the rates are lowest for the LMRF manufactures file; next come the LEAP estimates and then the BR estimates. When we turn to employment-based rates, the ASM greenfield and the LEAP rates are quite close. The ASM merger plus greenfield rates are close to the BR employment entry rate on average. The same story emerges for exit rates.

All of this shows that there are substantial similarities between the ASM and the LEAP files - at least when annual or longer-term (eight-year) entry and exit rates are calculated. We have shown in the main text that the remaining differential with the BR is eliminated when we measure the permanent entry rate the rate of entry of those new firms who will survive to five years.

In this section, we further explore similarities in the databases and look at inter-industry differences across databases. First, we ask how industry differences match up at a point in time by investigating the cross-sectional correlations for each year from 1989 to 1997. Then we examine the correlations between the time series of entry and exit rates for each industry. 
Table A1. Annual average short-term birth rate, 1989-97 (\%)

\begin{tabular}{|c|c|c|c|c|c|c|c|c|}
\hline $\begin{array}{l}\text { STAN } \\
\text { industry code }\end{array}$ & $\begin{array}{l}\text { ASM firm- } \\
\text { weighted entry } \\
\text { rate }\end{array}$ & $\begin{array}{l}\text { ASM greenfield } \\
\text { firm-weighted } \\
\text { entry rate }\end{array}$ & $\begin{array}{l}\text { BR firm- } \\
\text { weighted entry } \\
\text { rate }\end{array}$ & $\begin{array}{l}\text { LEAP firm- } \\
\text { weighted entry } \\
\text { rate }\end{array}$ & $\begin{array}{l}\text { ASM employment- } \\
\text { weighted entry } \\
\text { rate }\end{array}$ & $\begin{array}{l}\text { ASM employment- } \\
\text { weighted } \\
\text { greenfield entry } \\
\text { rate }\end{array}$ & $\begin{array}{l}\text { BR employment- } \\
\text { weighted entry } \\
\text { rate }\end{array}$ & $\begin{array}{l}\text { LEAP } \\
\text { employment- } \\
\text { weighted entry } \\
\text { rate }\end{array}$ \\
\hline $15 \mathrm{~A} 6$ & 8.3 & 7.2 & 17.6 & 11.9 & 5.6 & 1.5 & 12.1 & 1.0 \\
\hline $17 \mathrm{~T} 9$ & 7.4 & 6.7 & 19.2 & 13.9 & 5.0 & 2.4 & 9.3 & 1.7 \\
\hline 20 & 6.9 & 6.0 & 17.0 & 11.2 & 5.7 & 2.5 & 10.4 & 1.6 \\
\hline $21 \mathrm{~A} 2$ & 7.1 & 6.5 & 16.4 & 11.2 & 5.6 & 1.7 & 10.4 & 1.3 \\
\hline 23 & 11.6 & 9.4 & 23.7 & 16.0 & 5.2 & 0.8 & 1.4 & 1.4 \\
\hline 2423 & 11.7 & 8.0 & 19.1 & 12.2 & 5.0 & 0.8 & 11.7 & 2.4 \\
\hline $24 \times 2423$ & 8.9 & 7.0 & 16.8 & 10.4 & 4.1 & 1.4 & 10.7 & 1.0 \\
\hline 25 & 8.7 & 7.1 & 17.0 & 10.5 & 6.1 & 2.5 & 12.2 & 1.2 \\
\hline 26 & 7.8 & 6.8 & 15.7 & 10.1 & 5.5 & 2.4 & 10.9 & 1.2 \\
\hline 27 & 7.3 & 6.2 & 17.7 & 11.2 & 3.4 & 0.6 & 7.0 & 1.0 \\
\hline 28 & 7.1 & 6.5 & 13.5 & 8.4 & 6.3 & 3.9 & 10.5 & 1.4 \\
\hline 29 & 7.6 & 6.5 & 15.6 & 9.9 & 5.8 & 2.7 & 11.5 & 1.5 \\
\hline 30 & 12.2 & 10.5 & 20.7 & 13.1 & 7.0 & 4.1 & 14.0 & 1.4 \\
\hline 31 & 8.5 & 7.2 & 15.6 & 10.1 & 4.9 & 1.8 & 11.6 & 0.9 \\
\hline 32 & 9.9 & 8.4 & 17.8 & 11.0 & 7.1 & 1.5 & 5.7 & 1.0 \\
\hline 34 & 8.8 & 6.9 & 15.5 & 8.9 & 4.0 & 1.1 & 6.6 & 0.5 \\
\hline 351 & 8.4 & 8.2 & 18.6 & 12.9 & 5.3 & 2.7 & 7.8 & 1.2 \\
\hline $352 A 9$ & 8.9 & 6.3 & 26.7 & 18.2 & 11.0 & 1.1 & 26.8 & 3.0 \\
\hline 353 & 8.5 & 7.4 & 16.8 & 9.8 & 1.2 & 0.4 & 3.5 & 0.2 \\
\hline $36 \mathrm{~A} 7$ & 8.0 & 7.5 & 17.7 & 12.3 & 7.1 & 3.9 & 12.0 & 1.9 \\
\hline Average & 8.7 & 7.3 & 17.9 & 11.7 & 5.6 & 2.0 & 10.3 & 1.3 \\
\hline
\end{tabular}
2) For a listing of industry names, see Table $A 5$. 
DSTI/DOC(2002)3

Table A2. Annual average short-term death rate, 1989-97 (\%)

\begin{tabular}{|c|c|c|c|c|c|c|c|c|}
\hline $\begin{array}{l}\text { STAN } \\
\text { industry code }\end{array}$ & $\begin{array}{c}\text { ASM firm- } \\
\text { weighted death } \\
\text { rate }\end{array}$ & $\begin{array}{c}\text { ASM firm- } \\
\text { weighted } \\
\text { closedown death } \\
\text { rate }\end{array}$ & $\begin{array}{l}\text { BR firm- } \\
\text { weighted } \\
\text { death rate }\end{array}$ & $\begin{array}{l}\text { LEAP firm- } \\
\text { weighted death } \\
\text { rate }\end{array}$ & $\begin{array}{l}\text { ASM employment- } \\
\text { weighted death } \\
\text { rate }\end{array}$ & $\begin{array}{c}\text { ASM employment- } \\
\text { weighted } \\
\text { closedown death } \\
\text { rate }\end{array}$ & $\begin{array}{l}\text { BR employment- } \\
\text { weighted death } \\
\text { rate }\end{array}$ & $\begin{array}{c}\text { LEAP } \\
\text { employment- } \\
\text { weighted death } \\
\text { rate }\end{array}$ \\
\hline $15 \mathrm{~A} 6$ & 7.5 & 6.0 & 14.3 & 9.2 & 5.0 & 1.2 & 12.5 & 1.5 \\
\hline $17 \mathrm{~T} 9$ & 10.1 & 9.4 & 18.3 & 14.2 & 6.1 & 3.8 & 11.4 & 2.3 \\
\hline 20 & 8.0 & 6.9 & 16.0 & 11.6 & 5.7 & 2.5 & 12.0 & 1.8 \\
\hline $21 \mathrm{~A} 2$ & 8.0 & 7.2 & 15.3 & 11.1 & 4.9 & 1.5 & 13.2 & 1.7 \\
\hline 23 & 7.6 & 4.9 & 17.3 & 10.0 & 3.2 & 0.4 & 5.9 & 0.4 \\
\hline 2423 & 8.9 & 4.9 & 14.1 & 7.6 & 4.6 & 0.8 & 10.9 & 2.5 \\
\hline $24 \times 2423$ & 7.9 & 5.9 & 14.1 & 8.6 & 3.0 & 1.2 & 11.7 & 1.2 \\
\hline 25 & 7.4 & 5.8 & 14.4 & 8.7 & 5.4 & 2.0 & 12.0 & 1.5 \\
\hline 26 & 7.2 & 5.9 & 14.1 & 9.6 & 4.5 & 1.8 & 10.3 & 1.4 \\
\hline 27 & 7.9 & 6.9 & 14.9 & 9.3 & 2.2 & 0.6 & 6.4 & 0.4 \\
\hline 28 & 6.4 & 5.7 & 11.8 & 7.4 & 5.0 & 2.8 & 11.7 & 1.7 \\
\hline 29 & 7.4 & 6.1 & 13.0 & 8.0 & 6.1 & 2.4 & 11.0 & 1.9 \\
\hline 30 & 11.7 & 10.1 & 17.7 & 11.1 & 7.7 & 4.5 & 15.0 & 1.6 \\
\hline 31 & 7.5 & 6.4 & 13.0 & 8.5 & 3.6 & 2.0 & 14.0 & 1.2 \\
\hline 32 & 8.7 & 7.1 & 15.8 & 9.6 & 3.7 & 1.3 & 7.3 & 1.1 \\
\hline 34 & 8.5 & 6.2 & 14.1 & 8.6 & 4.2 & 1.0 & 7.7 & 0.6 \\
\hline 351 & 10.7 & 10.0 & 18.6 & 14.4 & 4.6 & 2.0 & 10.4 & 1.9 \\
\hline $352 A 9$ & 13.2 & 10.3 & 21.0 & 14.0 & 14.2 & 4.0 & 25.0 & 3.0 \\
\hline 353 & 8.7 & 7.3 & 15.1 & 9.8 & 1.4 & 0.4 & 3.9 & 0.4 \\
\hline $36 \mathrm{~A} 7$ & 8.4 & 7.8 & 15.9 & 11.8 & 7.2 & 4.1 & 13.7 & 2.6 \\
\hline Average & 8.6 & 7.1 & 15.4 & 10.2 & 5.1 & 2.0 & 11.3 & 1.5 \\
\hline
\end{tabular}

1) Employment in the LEAP file is derived from first-y
2) For a listing of industry names, see Table A5. 
Table A3. Long-term birth rate, 1989-97 (\%)

\begin{tabular}{|c|c|c|c|c|c|c|c|c|}
\hline $\begin{array}{l}\text { STAN } \\
\text { industry code }\end{array}$ & $\begin{array}{c}\text { ASM firm- } \\
\text { weighted entry } \\
\text { rate }\end{array}$ & $\begin{array}{l}\text { ASM greenfield } \\
\text { firm-weighted } \\
\text { entry rate }\end{array}$ & $\begin{array}{l}\text { BR firm- } \\
\text { weighted entry } \\
\text { rate }\end{array}$ & $\begin{array}{l}\text { LEAP firm- } \\
\text { weighted entry } \\
\text { rate }\end{array}$ & $\begin{array}{l}\text { ASM employment- } \\
\text { weighted entry } \\
\text { rate }\end{array}$ & $\begin{array}{c}\text { ASM employment- } \\
\text { weighted } \\
\text { greenfield entry } \\
\text { rate }\end{array}$ & $\begin{array}{l}\text { BR employment- } \\
\text { weighted entry } \\
\text { rate }\end{array}$ & $\begin{array}{c}\text { LEAP } \\
\text { employment- } \\
\text { weighted entry } \\
\text { rate }\end{array}$ \\
\hline $15 \mathrm{~A} 6$ & 45.9 & 37.8 & 71.6 & 56.6 & 42.4 & 10.0 & 61.2 & 9.0 \\
\hline 17T9 & 41.8 & 36.3 & 72.1 & 57.5 & 34.2 & 13.9 & 45.8 & 17.6 \\
\hline 20 & 43.0 & 36.7 & 67.1 & 48.6 & 32.4 & 13.8 & 49.4 & 16.4 \\
\hline $21 \mathrm{~A} 2$ & 43.3 & 39.1 & 62.8 & 47.9 & 35.4 & 10.1 & 53.6 & 12.3 \\
\hline 23 & 48.9 & 35.2 & 82.4 & 69.8 & 34.0 & 5.4 & 3.1 & 14.5 \\
\hline 2423 & 61.3 & 40.3 & 65.3 & 62.3 & 44.2 & 5.7 & 51.8 & 25.4 \\
\hline $24 \times 2423$ & 50.3 & 37.4 & 77.4 & 48.6 & 33.1 & 10.9 & 54.3 & 12.6 \\
\hline 25 & 50.6 & 39.8 & 67.5 & 47.7 & 44.6 & 13.3 & 55.6 & 16.5 \\
\hline 26 & 42.8 & 35.6 & 62.1 & 43.8 & 38.5 & 12.0 & 27.5 & 11.8 \\
\hline 27 & 40.7 & 32.6 & 64.2 & 47.4 & 50.4 & 3.6 & 37.6 & 12.5 \\
\hline 28 & 42.5 & 38.2 & 60.5 & 41.8 & 36.1 & 21.9 & 49.9 & 16.3 \\
\hline 29 & 45.8 & 38.1 & 66.5 & 48.8 & 41.4 & 17.7 & 52.7 & 16.7 \\
\hline 30 & 64.7 & 54.0 & 75.6 & 57.1 & 28.5 & 17.4 & 61.9 & 16.2 \\
\hline 31 & 49.4 & 40.3 & 66.6 & 50.2 & 29.8 & 9.2 & 55.4 & 12.5 \\
\hline 32 & 57.2 & 47.1 & 71.1 & 51.2 & 54.7 & 11.2 & 34.4 & 13.0 \\
\hline 34 & 49.4 & 36.3 & 64.8 & 42.3 & 38.1 & 7.1 & 36.5 & 7.0 \\
\hline 351 & 50.2 & 46.6 & 70.3 & 52.3 & 40.3 & 15.9 & 42.4 & 17.8 \\
\hline $352 A 9$ & 52.6 & 36.8 & 88.3 & 73.0 & 78.2 & 4.5 & 80.5 & 15.2 \\
\hline 353 & 48.3 & 38.9 & 62.7 & 44.1 & 10.8 & 2.7 & 10.8 & 2.3 \\
\hline $36 \mathrm{~A} 7$ & 43.7 & 40.4 & 67.3 & 52.5 & 41.2 & 18.3 & 55.3 & 20.0 \\
\hline Average & 48.6 & 39.4 & 69.3 & 52.2 & 39.4 & 11.2 & 46.0 & 14.3 \\
\hline
\end{tabular}

2) For a listing of industry names, see Table A5. 
DSTI/DOC(2002)3

Table A4. Long-term death rate, 1989-97 (\%)

\begin{tabular}{|c|c|c|c|c|c|c|c|c|}
\hline $\begin{array}{l}\text { STAN } \\
\text { industry } \\
\text { code }\end{array}$ & $\begin{array}{l}\text { ASM firm- } \\
\text { weighted death } \\
\text { rate }\end{array}$ & $\begin{array}{c}\text { ASM firm- } \\
\text { weighted } \\
\text { closedown death } \\
\text { rate }\end{array}$ & $\begin{array}{l}\text { BR firm- } \\
\text { weighted } \\
\text { death rate }\end{array}$ & $\begin{array}{l}\text { LEAP firm- } \\
\text { weighted death } \\
\text { rate }\end{array}$ & $\begin{array}{l}\text { ASM employment- } \\
\text { weighted } \\
\text { closedown death } \\
\text { rate }\end{array}$ & $\begin{array}{l}\text { ASM employment- } \\
\text { weighted death } \\
\text { rate }\end{array}$ & $\begin{array}{l}\text { BR employment- } \\
\text { weighted death } \\
\text { rate }\end{array}$ & $\begin{array}{c}\text { LEAP } \\
\text { employment- } \\
\text { weighted death } \\
\text { rate }\end{array}$ \\
\hline $15 \mathrm{~A} 6$ & 49.7 & 38.5 & 56.1 & 39.5 & 7.5 & 31.9 & 52.2 & 15.7 \\
\hline $17 \mathrm{~T} 9$ & 60.4 & 54.7 & 67.5 & 57.4 & 28.6 & 46.8 & 54.2 & 30.1 \\
\hline 20 & 50.8 & 42.7 & 61.6 & 49.5 & 20.1 & 41.0 & 51.7 & 19.8 \\
\hline $21 \mathrm{~A} 2$ & 50.7 & 44.2 & 57.2 & 47.4 & 11.0 & 35.4 & 50.9 & 14.1 \\
\hline 23 & 55.0 & 42.0 & 65.7 & 37.1 & 1.5 & 9.2 & 25.5 & 4.4 \\
\hline 2423 & 55.6 & 33.3 & 53.9 & 37.1 & 4.5 & 41.7 & 41.1 & 26.8 \\
\hline $24 \times 2423$ & 52.2 & 38.4 & 59.1 & 37.1 & 6.8 & 30.2 & 50.1 & 15.5 \\
\hline 25 & 48.8 & 37.3 & 56.9 & 39.1 & 13.2 & 36.7 & 48.0 & 15.9 \\
\hline 26 & 47.4 & 36.3 & 54.9 & 42.1 & 13.2 & 35.4 & 48.7 & 14.3 \\
\hline 27 & 50.3 & 43.2 & 58.0 & 40.3 & 4.3 & 14.9 & 33.2 & 4.2 \\
\hline 28 & 43.2 & 36.9 & 51.2 & 36.5 & 21.5 & 35.9 & 54.4 & 23.0 \\
\hline 29 & 48.7 & 38.6 & 55.0 & 38.4 & 20.2 & 46.4 & 45.5 & 20.1 \\
\hline 30 & 66.7 & 51.4 & 66.5 & 49.2 & 18.3 & 37.5 & 60.1 & 14.3 \\
\hline 31 & 51.5 & 41.7 & 54.5 & 41.0 & 10.6 & 25.8 & 58.8 & 15.0 \\
\hline 32 & 55.6 & 43.5 & 63.3 & 45.6 & 9.5 & 35.0 & 34.2 & 12.8 \\
\hline 34 & 56.6 & 41.5 & 58.3 & 40.3 & 7.8 & 31.9 & 39.2 & 6.9 \\
\hline 351 & 62.7 & 54.8 & 68.7 & 59.5 & 16.9 & 36.9 & 48.8 & 23.1 \\
\hline $352 A 9$ & 62.5 & 37.5 & 75.6 & 51.8 & 2.7 & 77.8 & 66.9 & 32.9 \\
\hline 353 & 52.2 & 43.5 & 56.0 & 44.7 & 2.8 & 19.4 & 20.0 & 4.5 \\
\hline $36 \mathrm{~A} 7$ & 52.4 & 46.7 & 59.9 & 50.4 & 28.9 & 49.4 & 62.9 & 29.1 \\
\hline Average & 53.6 & 42.3 & 60.0 & 44.2 & 12.5 & 36.0 & 47.3 & 17.1 \\
\hline
\end{tabular}


DSTI/DOC(2002)3

Table A5. Industries used

\begin{tabular}{|ll|}
\hline OECD STAN code & Industry title \\
\hline 15 A6 & Food products, beverages and tobacco \\
17 T9 & Textiles, textile products, leather and footwear \\
20 & Wood and products of wood and cork \\
21 A2 & Pulp, paper, paper products, printing and publishing \\
23 & Coke, refined petroleum products and nuclear fuel \\
2423 & Pharmaceuticals \\
$24 \times 2423$ & Chemicals excluding pharmaceuticals \\
25 & Rubber and plastics products \\
26 & Other non-metallic mineral products \\
27 & Basic metals \\
28 & Fabricated metal products, except machinery and equipment \\
29 & Machinery and equipment n.e.c. \\
30 & Office, accounting and computing machinery \\
31 & Electrical machinery and apparatus, n.e.c. \\
32 & Radio, television and communication equipment \\
34 & Motor vehicles, trailers and semi-trailers \\
351 & Building and repairing of ships and boats \\
352 A9 & Railroad equipment and transport equipment n.e.c. \\
353 & Aircraft and spacecraft \\
36 A7 & Manufacturing n.e.c.; recycling \\
\hline
\end{tabular}

Table A6. Cross-sectional industry correlations between BR and LEAP entry rates

\begin{tabular}{lcccc}
\hline Year & $\begin{array}{c}\text { BR-LEAP } \\
\text { firm birth rate }\end{array}$ & $\begin{array}{c}\text { BR-LEAP } \\
\text { firm death rate }\end{array}$ & $\begin{array}{c}\text { BR-LEAP } \\
\text { employment birth rate }\end{array}$ & $\begin{array}{c}\text { BR-LEAP } \\
\text { employment death rate }\end{array}$ \\
\hline 1989 & 0.56 & 0.76 & 0.07 & 0.51 \\
1990 & 0.77 & 0.65 & 0.81 & -0.06 \\
1991 & 0.81 & 0.63 & 0.47 & 0.31 \\
1992 & 0.34 & 0.65 & 0.38 & 0.22 \\
1993 & 0.71 & 0.68 & 0.86 & 0.89 \\
1994 & 0.95 & 0.89 & 0.06 & 0.05 \\
1995 & 0.88 & 0.90 & -0.03 & 0.30 \\
1996 & 0.92 & 0.62 & 0.02 & 0.47 \\
1997 & 0.96 & 0.87 & -0.10 & 0.17 \\
Average & 0.77 & & & \\
\hline
\end{tabular}

Note: Employment in the LEAP file is derived from first-year employment.

a)

\section{Cross-sectional correlations}

If we use the entry and exit databases to investigate differences in industry characteristics that are related to differences in industry entry rates, we need to know whether the cross-sectional differences across industries are more or less the same for all the databases. To answer this question, we compare the cross-sectional correlations for comparable industries-about 20 of the OECD STAN industries. Correlations were calculated between the firm-weighted and the employment-weighted entry rates for each of the years between 1989 and 1997 for the BR administrative and the LEAP databases. The results are reported in Table A6. 
Entry rates and exit rates at the industry level from these two databases are closely correlated. On average, the correlations are over .70 when we calculate the rate as the number of new firms divided by the total number of firms. On the other hand, the employment-weighted rates - the employment in new firms divided by total employment - are not as highly correlated. Here the correlations averaged about .30. This corroborates our earlier finding that the employment size on the Business Register is quite different than the imputed size on the LEAP file.

The correlations between LEAP and the ASM one-year firm entry rates at the industry level are presented in Table A7. In this case, the entry rates between LEAP and the ASM file across industries are not correlated - the average is zero or negative. The correlations between the employment entry rates are also quite small. In contrast, there is more correlation between the employment death rates - between 0.31 and 0.39 . The same pattern exists for ASM-BR industry correlation rates.

Table A7. Cross-sectional industry correlations between LEAP and ASM entry rates

\begin{tabular}{|c|c|c|c|c|c|c|c|c|}
\hline Year & $\begin{array}{l}\text { LEAP-ASM } \\
\text { (all): } \\
\text { firm birth } \\
\text { rate }\end{array}$ & $\begin{array}{c}\text { LEAP-ASM } \\
\text { (greenfield): } \\
\text { firm birth } \\
\text { rate }\end{array}$ & $\begin{array}{l}\text { LEAP-ASM } \\
\text { (all): } \\
\text { firm death } \\
\text { rate }\end{array}$ & $\begin{array}{c}\text { LEAP-ASM } \\
\text { (closedown): } \\
\text { firm death } \\
\text { rate }\end{array}$ & $\begin{array}{l}\text { LEAP-ASM } \\
\text { (all): } \\
\text { employment } \\
\text { birth rate }\end{array}$ & $\begin{array}{l}\text { LEAP-ASM } \\
\text { (greenfield): } \\
\text { employment } \\
\text { birth rate }\end{array}$ & $\begin{array}{l}\text { LEAP-ASM } \\
\text { (all): } \\
\text { employment } \\
\text { death rate }\end{array}$ & $\begin{array}{l}\text { LEAP-ASM } \\
\text { (closedown): } \\
\text { employment } \\
\text { death rate }\end{array}$ \\
\hline 1989 & -0.27 & -0.25 & 0.00 & 0.14 & +0.38 & 0.35 & +0.58 & 0.75 \\
\hline 1990 & -0.20 & -0.12 & 0.78 & 0.80 & +0.54 & 0.69 & -0.16 & 0.66 \\
\hline 1991 & +0.52 & -0.28 & 0.20 & 0.21 & -0.03 & 0.59 & +0.66 & 0.77 \\
\hline 1992 & +0.52 & 0.45 & 0.63 & 0.74 & +0.00 & 0.20 & +0.75 & 0.84 \\
\hline 1993 & -0.38 & -0.39 & 0.41 & 0.44 & -0.17 & -0.22 & -0.21 & -0.09 \\
\hline 1994 & -0.07 & -0.42 & 0.09 & 0.05 & +0.01 & 0.18 & +0.28 & 0.33 \\
\hline 1995 & +0.08 & -0.04 & 0.57 & 0.58 & -0.19 & 0.11 & +0.53 & 0.28 \\
\hline 1996 & -0.21 & -0.34 & 0.47 & 0.64 & -0.10 & -0.02 & +0.06 & 0.05 \\
\hline 1997 & +0.06 & 0.22 & & & -0.24 & -0.12 & & \\
\hline Average & 0.00 & -0.13 & 0.39 & 0.45 & 0.02 & 0.19 & 0.31 & 0.45 \\
\hline
\end{tabular}

Note: Employment in the LEAP file is derived from first-year employment.

This evidence indicates that the cross-sectional correlations in any particular year may not be particularly high, suggesting that any cross-sectional analysis may be sensitive to the database chosen. One possible way of reducing this problem is to take the industry average over a period of time. In Table A8, we report the correlations of cross-industry entry and exit rates when the latter are averaged over the period from 1989 to 1997. The correlations between the two administrative databases are at least 0.9 for the firm-based rates. The correlations are between 0.7 and 0.8 for the employment rates, thereby confirming that longer-run averages of yearly entry and exit rates from both administrative databases yield quite similar cross-industry patterns.

It is also noteworthy that the correlations between the ASM and both administrative databases are generally larger for exit rates. They are also high for the employment birth rates when the ASM entry rate that includes mergers is used. The correlations for the death rates range from 0.7 to 0.9 . 
DSTI/DOC(2002)3

Table A8. Cross-sectional industry correlations based on average rates, from 1989-97

\begin{tabular}{lcccc}
\hline Year & $\begin{array}{c}\text { Average firm } \\
\text { birth rate }\end{array}$ & $\begin{array}{c}\text { Average firm } \\
\text { death rate }\end{array}$ & $\begin{array}{c}\text { Average employment } \\
\text { birth rate }\end{array}$ & $\begin{array}{c}\text { Average employment } \\
\text { death rate }\end{array}$ \\
\hline & & & & 0.72 \\
BR-LEAP & 0.97 & 0.89 & 0.79 & 0.78 \\
BR-ASM (all) & 0.56 & 0.84 & 0.24 & 0.71 \\
BR-ASM (greenfield) & 0.37 & 0.79 & 0.78 & 0.77 \\
LEAP-ASM (all) & 0.42 & 0.71 & 0.18 & 0.73 \\
LEAP-ASM (greenfield) & 0.29 & 0.85 &
\end{tabular}

Note: Employment in the LEAP file is derived from first-year employment.

All of this suggests that comparisons should average results over time if they want to be robust and that they should focus more on employment-weighted measures since database-specific idiosyncrasies will be reflected in dramatic differences in firm-number entry and exit rates. This occurs because databases can differ dramatically in their ability to pick up very small firms. This will lead to large differences in the rates of entry when measured using number of firms, but relatively smaller differences using employment rates since the firms that are being picked up at the margin by the more comprehensive databases are generally smaller than average. These results also show that entry rates using administrative databases and employment can include a substantial merger component and should be so interpreted.

Table A9. Cross-sectional industry correlations based on long-run entry and exit rates, between 1989-97

\begin{tabular}{|c|c|c|c|c|}
\hline Year & $\begin{array}{l}\text { Average firm birth } \\
\text { rate }\end{array}$ & $\begin{array}{l}\text { Average firm death } \\
\text { rate }\end{array}$ & $\begin{array}{c}\text { Average } \\
\text { employment birth } \\
\text { rate }\end{array}$ & $\begin{array}{c}\text { Average } \\
\text { employment death } \\
\text { rate }\end{array}$ \\
\hline BR-LEAP & 0.82 & 0.70 & 0.40 & 0.73 \\
\hline BR-ASM (all) & 0.38 & 0.82 & 0.49 & 0.71 \\
\hline BR-ASM (greenfield) & 0.11 & 0.53 & 0.33 & 0.53 \\
\hline LEAP-ASM (all) & 0.40 & 0.64 & 0.33 & 0.85 \\
\hline LEAP-ASM (greenfield) & 0.07 & 0.80 & 0.43 & 0.54 \\
\hline
\end{tabular}

Note: Employment in the LEAP file is derived from first-year employment.

In the main body of the paper, we show that long-run entry rates calculated from the different databases are much more similar than annual rates calculated from the same databases. That is, entry rates that are calculated from the number of firms that existed in 1997 but not in 1989 are more similar than annual rates of entry and exit calculated by comparing any two years in the period. We also compare the industry correlations using these longer-run entry and exit rates (Table A9). Here, the correlations between the two administrative data sources are once again highest for firm exit rates. However, in all other cases, the correlations with the results from the ASM file and one of the two administrative files is lower than before. 
Studies of the extent to which entry and exit rates respond to macroeconomic factors require time-series data. At issue then is the extent to which the various series from each of the three databases follow different paths. The birth and death rates for the BR, LEAP and ASM are reported in Figures A1, A2, and A3, respectively. The firm-based entry rates from the manufacturing file show a sharp drop-off during the recession of the early 1990s, while neither of the other two series shows this behaviour. The former is partially explained by the falling coverage of the manufacturing file during this time period. Nevertheless, the failure of the two administrative series to show any fall during the recession is also suggestive of certain unexplained idiosyncrasies. A comparison of the employment birth rates also indicates that the ASM entry rates decline during the early 1990s, but this time the administrative data from the BR also show a decline. The employment size of new firms in this database responds in a pro-cyclical fashion, although once again, the LEAP file shows little counter-cyclicality.

The firm death rates contained in Figure A2 and A3 reveal a certain amount of pro-cyclicality in both the ASM and in the LEAP administrative file. Both increase slightly in the early 1990s, but whereas the ASM death rates decline steadily during the subsequent decade when growth steadily increases, the death rates in the LEAP file vary around a constant value. The death rates derived from the Business Register (Figure A1) follow a decline up to 1993 but then increase afterwards, much as do the rates derived from LEAP.

Much the same story is told by the employment death rates that come from the BR, but here the turnaround in 1992 is more dramatic. Larger firms are dying in this database as the period progresses. This trend is born out by the ASM employment death rates, which increase relative to firm numbers death rates. Once again, the LEAP rates are surprisingly steady throughout the period.

In order to investigate whether the various data sources follow the same time profile, we correlate the entry and exit rates for each industry for the BR and LEAP files (Table A10). These correlations vary from negative values to as high as .9. The average correlation for the entry and exit rates using firm numbers is around .5. However, for employment entry and exit rates, the correlations are much lower. This pattern does not vary across the sub-periods 1989-93 and 1993-97.

The correlations between both the LEAP and the BR rates with the ASM rates (not reported here) are considerably lower for entry rates - around 0 . The correlations for death rates are around .40. The ASM entry rates decrease more in the early 1990s than the rates produced from the other two files, while the course of the death rates is somewhat more similar.

Is one series better than another for studying the times-series properties of entry and exit? The ASM probably overstated the rate at which entry declined because of its temporary under-coverage. On the other hand, the administrative files are probably too stable. This could simply be that other changes in organisation structure that are false births are being picked up as entrants during the recession, and the editing process that focuses on larger firms misses this. If firms are more likely to go through reorganisation during recessions and these reorganisations are not being culled from the administrative data, this would explain the relative stability in these series. While some attempt is made to remove the false births and deaths from the LEAP administrative file, these changes are not made for the smaller firms in the sample and it is likely that it is here that there is the greatest problem. 
Table A10. Cross-sectional industry correlations between LEAP and BR entry rates, 1989-97

\begin{tabular}{|c|c|c|c|c|}
\hline Industry & $\begin{array}{c}\text { BR-LEAP } \\
\text { firm birth rate }\end{array}$ & $\begin{array}{c}\text { BR-LEAP } \\
\text { firm death rate }\end{array}$ & $\begin{array}{c}\text { BR-LEAP } \\
\text { employment birth rate }\end{array}$ & $\begin{array}{c}\text { BR-LEAP } \\
\text { employment death rate }\end{array}$ \\
\hline $15 \mathrm{~A} 6$ & 0.89 & 0.10 & 0.13 & 0.01 \\
\hline $17 \mathrm{T9}$ & 0.30 & 0.33 & 0.23 & 0.35 \\
\hline 20 & 0.25 & 0.63 & -0.41 & 0.16 \\
\hline $21 \mathrm{~A} 2$ & 0.36 & 0.32 & -0.55 & -0.32 \\
\hline 23 & 0.57 & 0.14 & 0.257 & -0.10 \\
\hline 2423 & 0.77 & -0.14 & 0.05 & 0.69 \\
\hline $24^{\star} 2423$ & 0.43 & 0.47 & 0.59 & 0.85 \\
\hline 25 & 0.24 & 0.51 & 0.51 & -0.01 \\
\hline 26 & 0.10 & -0.02 & -0.02 & -0.12 \\
\hline 27 & 0.53 & 0.41 & 0.55 & 0.78 \\
\hline 28 & 0.24 & 0.66 & 0.03 & 0.10 \\
\hline 29 & 0.57 & 0.63 & -0.52 & 0.22 \\
\hline 30 & 0.21 & 0.69 & -0.01 & -0.04 \\
\hline 31 & 0.57 & 0.46 & 0.35 & 0.55 \\
\hline 32 & 0.54 & 0.71 & -0.27 & 0.72 \\
\hline 34 & 0.21 & 0.72 & -0.17 & 0.01 \\
\hline 351 & 0.92 & 0.82 & 0.19 & 0.07 \\
\hline $352 A 9$ & 0.71 & 0.58 & 0.38 & 0.06 \\
\hline 353 & 0.61 & 0.60 & 0.13 & 0.35 \\
\hline $36 \mathrm{~A} 7$ & -0.39 & 0.81 & -0.33 & -0.10 \\
\hline Average & 0.43 & 0.47 & 0.05 & 0.22 \\
\hline
\end{tabular}

\section{Summary}

In the main body of the paper, we show that entry rates derived from different and equally legitimate data sources can vary more in the short than in the longer run. Each of the data sets yields annual rates of firm-based entry that can differ by up to five percentage points but yield essentially equivalent rates of entry when periods greater than five years are compared. This suggests that researchers who want to study those entrants who survive are less likely to produce disparate results if they focus on a longer-run entry rate -and that international comparisons should focus on this area. The time-series results also confirm this prescription. The short-run properties of all three sources leave something to be desired. All of this suggests that studies of structural change using longitudinal databases might best focus on longer-run than shorter-run change.

The data in the appendix also show that entry rates based on employment are less influenced by some of the idiosyncracies of population coverage but not by others. The exclusion of small firms has little impact on the employment-based entry rates, while the way in which mergers, control changes and other forms of reorganisation are treated has a large impact. There are a considerable number of control changes taking place each year in North American firms. If the Business Register that is used to measure entry cannot remove these, or only does so partially, then entry rates will be considerably higher than otherwise. International comparisons of entry need to carefully investigate how national sources treat mergers or control changes before comparing employment-based entry rates. It is likely that there is greater comparability across national databases in the way that the creation and destruction of establishments are treated. If so, it would be prudent to select a more internationally comparable entity, such as the establishment, for comparison purposes. 
Figure A1. BR birth and death rates - manufacturing aggregate

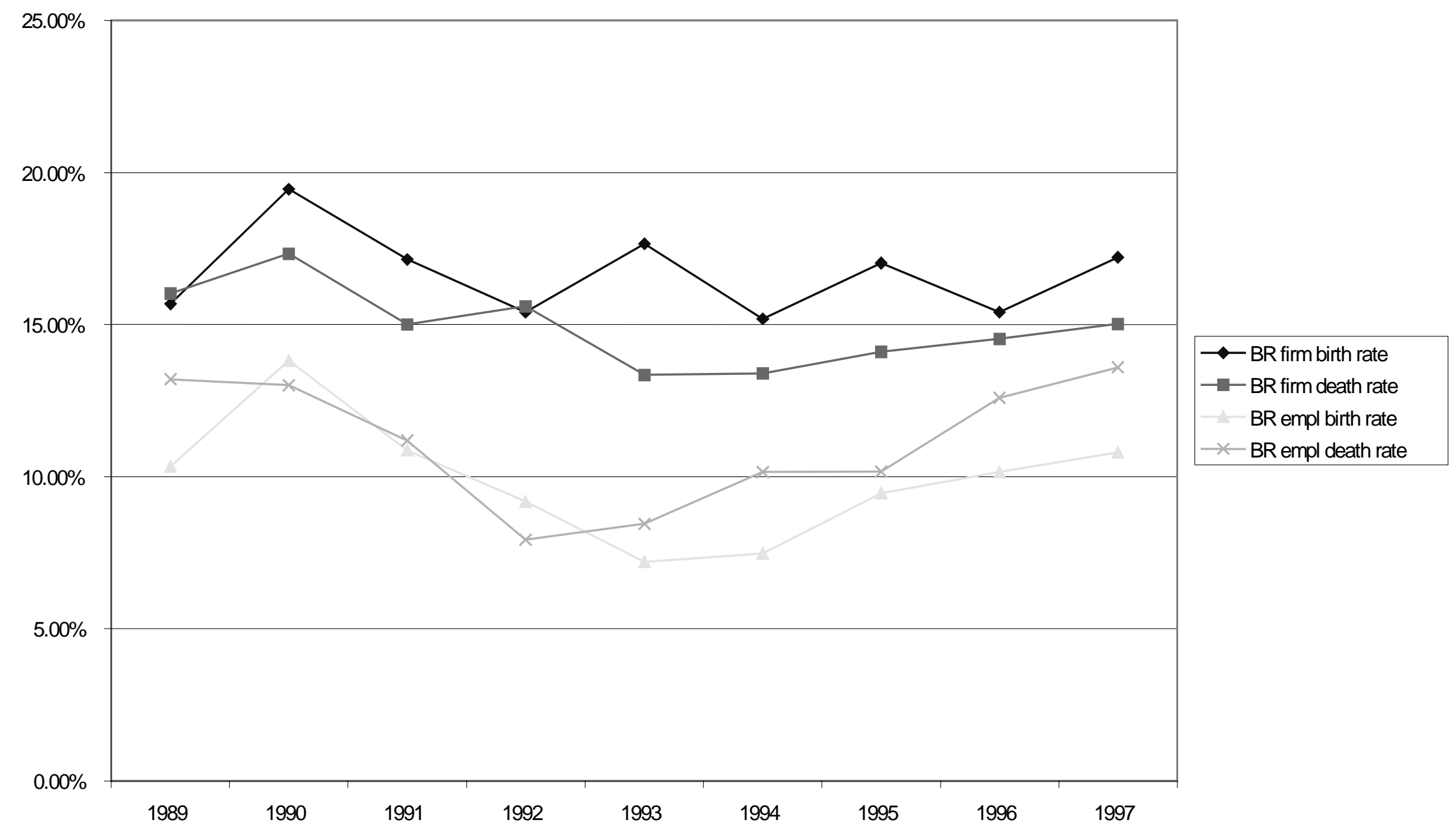


Figure A2. LEAP birth and death rates - manufacturing aggregate

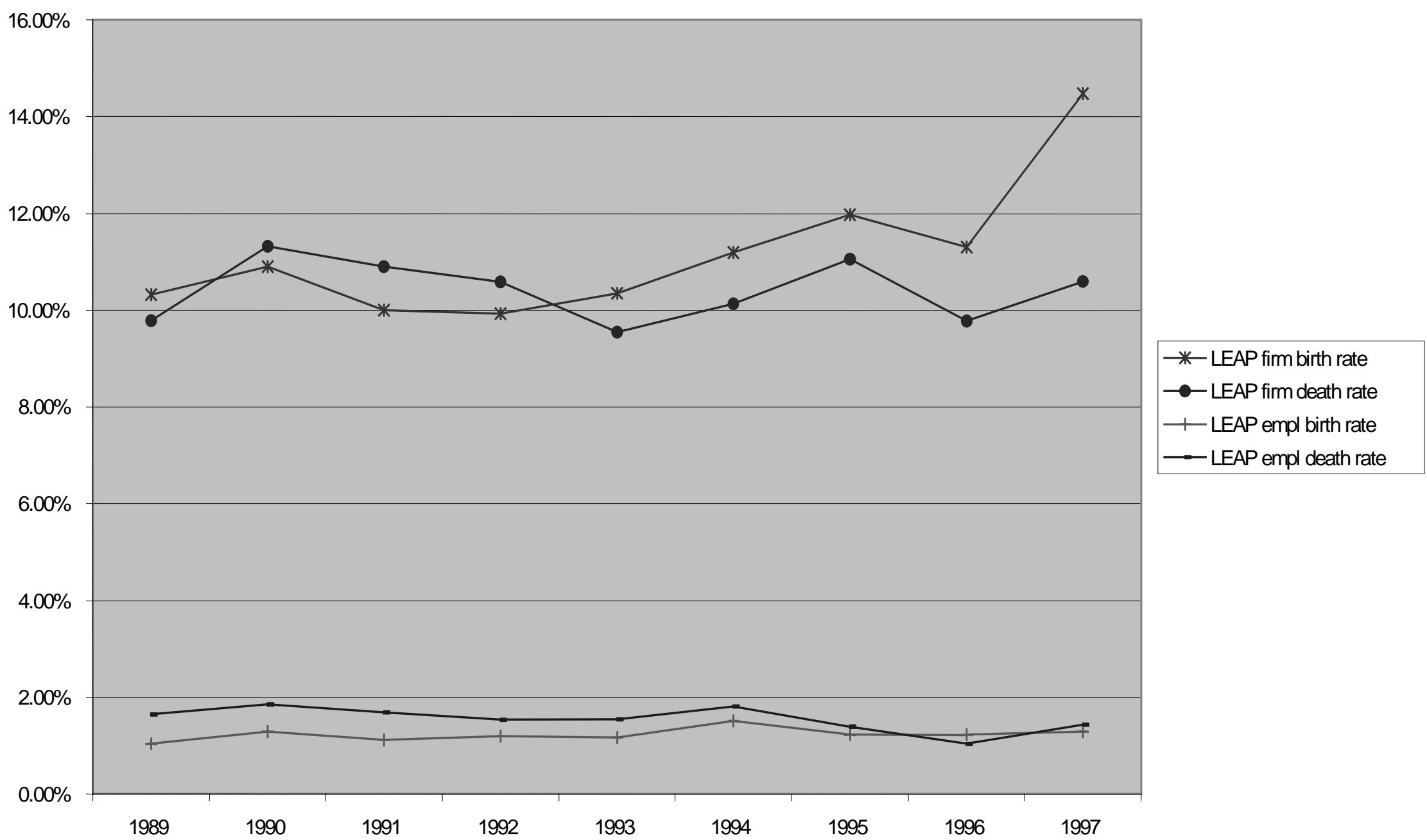




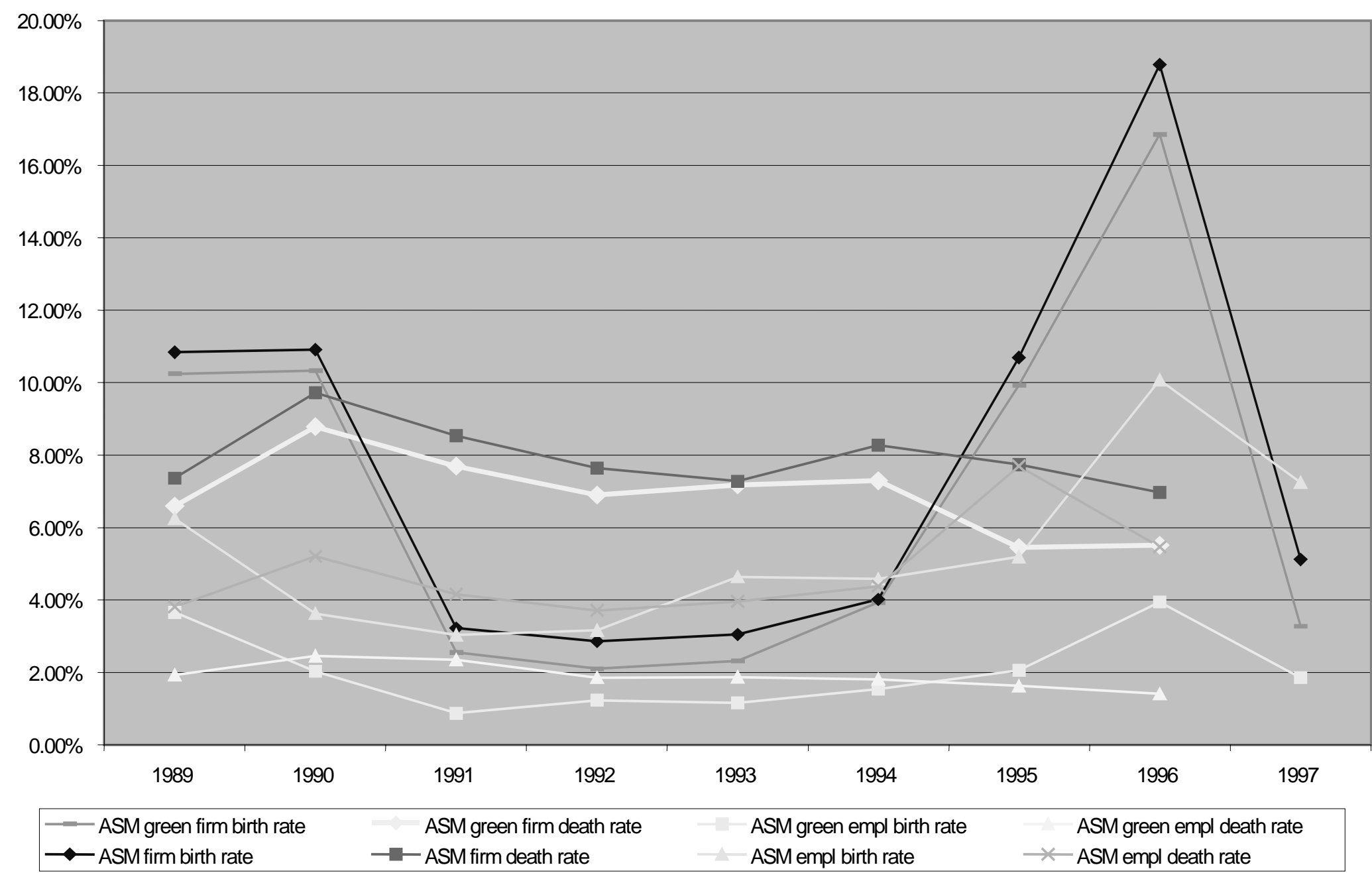


DSTI/DOC(2002)3

\section{REFERENCES}

Agarwal, R. and M. Gort (1996), "The Evolution of Markets and Entry, Exit and the Survival of Firms", Review of Economics and Statistics 78(3), pp. 489-98.

Audretsch, D.B. (1995), Innovation and Industry Evolution, The MIT Press.

Aw, B.Y, X. Chen and M.J. Roberts (1997), "Firm-level Evidence on Productivity Differentials, Turnover, and Exports in Taiwanese Manufacturing", in D.B. Audretsch and R.A. Thurik (eds.), Innovation, Industry Evolution and Employment, Cambridge University Press.

Bailey, M.N., C. Hulten and D. Campbell (1992), "Productivity Dynamics in Manufacturing Plants", Brookings Papers on Economic Activity: MicroEconomics 1992, pp. 187-267.

Baldwin, J.R. (1995), The Dynamics of Industrial Competition, Cambridge University Press.

Baldwin, J.R. (1996), "Productivity Growth, Plant Turnover and Restructuring in the Canadian Manufacturing Sector", in D. Mayes (ed.), Sources of Productivity Growth, Cambridge University Press.

Baldwin, J.R., L. Bian, R. Dupuy and G. Gellatly (2000), Failure Rates for New Canadian Firms: New Perspectives on Entry and Exit, Catalogue No. 61-526, Statistics Canada, Ottawa.

Baldwin, J.R., W. Chandler, C. Le and T. Papailiadis (1994), Strategies for Success: A Profile of Small and Medium-Sized Enterprises in Canada, Catalogue No. 61-523RE, Statistics Canada, Ottawa.

Baldwin, J.R., T. Dunne and J. Haltiwanger (1998), "A Comparison of Job Creation and Job Destruction in Canada and the United States", Review of Economics and Statistics 80, pp. 347-357.

Baldwin J.R., Dupuy, R. and W. Penner (1992), "Development of Longitudinal Panel Data from Business Registers: Canadian Experience", Statistical Journal of the United Nations 9(4), pp. 289-303.

Baldwin, J.R., R. Durand and J. Hosein (2001), "Restructuring and Productivity Growth in the Canadian Business Sector", Productivity Growth in Canada, Catalogue No. 15-204, pp. 25-38, Statistics Canada, Ottawa.

Baldwin, J.R. and P.K. Gorecki (1990), Structural Change and the Adjustment Process: Perspective on Firm Growth and Worker Turnover, Economic Council of Canada and Statistics Canada, Ministry of Supply and Services, Ottawa.

Baldwin, J.R. and P.K. Gorecki (1991), "Productivity Growth and the Competitive Process: The Role of Firm and Plant Turnover", in P.A. Geroski and J. Schwalbach (eds.), Entry and Market Contestability: An International Comparison, Basil Blackwell, Oxford. 


\section{DSTI/DOC(2002)3}

Baldwin, J.R. and M. Rafiquzzaman (1996), "Selection versus Evolutionary Learning: Learning and Postentry Performance", International Journal of Industrial Organization 13, pp. 501-522.

Cable, J. and J. Schwalbach (1991), "International Comparisons of Entry and Exit", in P.A. Geroski and J. Schwalbach (eds.), Entry and Market Contestability: An International Comparison, Basil Blackwell, Oxford.

Geroski, P.A. and J. Schwalbach (1991), Entry and Market Contestability: An International Comparison, Basil Blackwell, Oxford.

Griliches, Z. and H. Regev (1995), "Firm Productivity in Israeli Industry, 1979-1988", Journal of Econometrics 65, pp. 175-203.

Haltiwanger, J. (1998), "Measuring and Analyzing Aggregate Fluctuations: The Importance of Building from Micro-Economic Evidence”, St. Louis Fed. Reserve Bank Econ. Rev.

Kirzner, I. (1972), Competition and Entrepreneurship, University of Chicago Press, Chicago.

Knight, F.H. (1921), Risk, Uncertainty and Profit, Harper, New York.

Link, A.N. and B. Bozeman (1991), "Innovative Behavior in Small-Sized Firms", Small Business Economics 3, pp. 179-184.

Lin, Z., G. Picot and J. Yates (1999), "The Entry and Exit Dynamics of Self-Employment in Canada", Research Paper No. 134, Analytical Studies Division, Statistics Canada.

Mansfield, E. (1962), "Entry, Gibrat's Law, Innovation and the Growth of Firms", American Economic Review 52, pp. 1023-1051.

Neuman, H. (1978), "Strategic Groups and Structure-Performance Relationship", Review of Economics and Statistics 60, pp. 417-427.

OECD (1996), Job Creation and Loss: Analysis, Policy and Data Development, OECD, Paris.

OECD (2001), "Productivity and Firm Dynamics: Evidence from Microdata", OECD Economic Outlook No. 69, OECD, Paris.

Pakes, A. and R. Erickson (1988), "Empirical Implications of Alternative Models of Firm Dynamics", paper presented to a conference entitled "Dynamic Aspects of Firm and Industry Behaviour", National Bureau of Economic Research, Cambridge, Mass.

Rothwell, R. (1989), "Small Firms, Innovation and Industrial Change", Small Business Economics 1, pp. 51-64.

Rothwell, R. and W. Zegveld (1982), Innovation and the Small and Medium-Sized Firm, Frances Pinter, London.

Statistics Canada (1997a), Labour Force Update: The Self-Employed, Vol. 1: 3, Catalogue 71-005, Statistics Canada, Ottawa.

Statistics Canada (1997b), Labour Force Income Profiles. 
Statistics Canada (1999), A Longitudinal Analysis of Entrepreneurship in Canada, Small Area and Administrative Data Division, Statistics Canada.

Statistics Canada (2000), "The Duration of Self-Employment in Canada", Small Area and Administrative Data Division, Statistics Canada, unpublished mimeo.

Tompa, E., E. Papadaki, J. Patenaude and H. Roberge (2000), "A Longitudinal Analysis of Young Entrepreneurs in Canada", Statistics Canada, unpublished mimeo. 